University of Nebraska - Lincoln

DigitalCommons@University of Nebraska - Lincoln

$6-22-2019$

\title{
The antiquity of the Sahara Desert: New evidence from the mineralogy and geochemistry of Pliocene paleosols on the Canary Islands, Spain
}

Daniel R. Muhs

Joaquín Meco

James R. Budahn

Gary L. Skipp

Juan F. Betancort

See next page for additional authors

Follow this and additional works at: https://digitalcommons.unl.edu/usgsstaffpub

Part of the Geology Commons, Oceanography and Atmospheric Sciences and Meteorology Commons, Other Earth Sciences Commons, and the Other Environmental Sciences Commons

This Article is brought to you for free and open access by the US Geological Survey at DigitalCommons@University of Nebraska - Lincoln. It has been accepted for inclusion in USGS Staff -- Published Research by an authorized administrator of DigitalCommons@University of Nebraska - Lincoln. 


\section{Authors}

Daniel R. Muhs, Joaquín Meco, James R. Budahn, Gary L. Skipp, Juan F. Betancort, and Alejandro Lomoschitz 


\title{
The antiquity of the Sahara Desert: New evidence from the mineralogy and geochemistry of Pliocene paleosols on the Canary Islands, Spain
}

\author{
Daniel R. Muhs ${ }^{\mathrm{a}, *}$, Joaquín Meco ${ }^{\mathrm{b}}$, James R. Budahn ${ }^{\mathrm{a}}$, Gary L. Skipp ${ }^{\mathrm{a}}$, Juan F. Betancort ${ }^{\mathrm{b}}$, \\ Alejandro Lomoschitz ${ }^{\mathrm{c}}$ \\ ${ }^{a}$ U.S. Geological Survey, MS 980, Box 25046, Federal Center, Denver, CO 80225, USA \\ ${ }^{\mathrm{b}}$ Departamento de Biología, Universidad de Las Palmas de Gran Canaria, 35017 Las Palmas de Gran Canaria, Canary Islands, Spain \\ ${ }^{\mathrm{c}}$ Instituto de Oceanografía y Cambio Global, IOCAG - Unidad Asociada de I+D +i al CSIC, Universidad de Las Palmas de Gran Canaria, ULPGC, 35017 Las Palmas de \\ Gran Canaria, Canary Islands, Spain
}

\section{A R T I C L E I N F O}

\section{Keywords:}

Paleoclimate

Aridity

African dust

Clay minerals

Trace elements

\begin{abstract}
A B S T R A C T
The Sahara is the largest warm desert in the world, but its age has been controversial, with estimates ranging from Miocene to Holocene. Mineralogical and geochemical data show that paleosols of Pliocene to midPleistocene age on Fuerteventura and Gran Canaria in the Canary Islands have developed in part from inputs of dust from Africa. These paleosols contain quartz and mica, minerals that are abundant in African dust but are rare in the basaltic rocks that dominate the Canary Islands. Trace elements with minimal mobility, Sc, Cr, Hf, Th, and Ta as well as the rare earth elements, show that paleosols have compositions that are intermediate between those of local rocks and African-derived dust. Thus, results reported here and in a recently published study by others indicate that 9 paleosols record delivery of African dust to the Canary Islands between $\sim 4.8-2.8 \mathrm{Ma}$, $\sim 3.0-2.9 \mathrm{Ma}, \sim 2.3-1.46 \mathrm{Ma}$, and $\sim 0.4 \mathrm{Ma}$. A long-term paleosol record of African dust input agrees with deepsea records off the coast of western Africa that imply increased dust fluxes to the eastern Atlantic Ocean at $\sim 4.6 \mathrm{Ma}$. It is concluded that the Sahara Desert has been in existence as an arid-region dust source, at least intermittently, for much of the Pliocene and continuing into the Pleistocene.
\end{abstract}

\section{Introduction}

The Sahara (Fig. 1a) is the largest warm desert in the world. During certain times of the past, the region has experienced greater precipitation, such as during the late-glacial/early-Holocene African Humid Period (see reviews in deMenocal et al., 2000, and Quade et al., 2018). However, the present climate of the Sahara is hyperarid, primarily a function of the nearly continuous presence of the subtropical high-pressure cell (the Azores High) situated over North Africa. This high-pressure system, a function of Hadley cell circulation, separates the Sahara from the winter-moist Mediterranean climate zone to the north and the summer-moist savanna climate of the Sahel to the south. An additional factor that enhances aridity of the region is the presence of the east-west-trending Atlas Mountains of Morocco, Algeria, and Tunisia, which serve to shelter the Sahara from moisture sources originating in the north.

The timespan over which the Sahara has been arid has been highly controversial. Based on the gradual $(\sim 1.2 \mathrm{~cm} / \mathrm{yr})$ rate of Cenozoic African plate movement northwest to its present position (Geldmacher et al., 2005), where Africa could be situated under the dry, subsiding air of the subtropical high-pressure cell, a wide range of ages for aridity of the Sahara is permitted. Based on studies conducted within the Sahara itself or from modeling experiments, age estimates for the initiation of aridity range from the Holocene (Sincell, 1999; Claussen et al., 1999), to Pleistocene (Swezey, 1999; Kroepelin, 2006), to Pliocene (Swezey, 2006, 2009), and even Miocene (Schuster et al., 2006; Micheels et al., 2009; Zhang et al., 2014).

Indirect evidence for Saharan aridity, but with better age control, comes from the study of proxies for past vegetation in deep-sea cores off the coast of western Africa. As part of the Ocean Drilling Project (ODP), a number of cores have been raised from the eastern Atlantic from off Morocco to as far south as the Cape Verde Islands (Fig. 1a). Many of these cores record deposition history that spans the Pleistocene and some records extend to the Miocene. Based on studies of modern marine sediments off western Africa, Chenopodiaceae-Amaranthaceae (Cheno$\mathrm{Am})$ pollen is dominant, derived from the sparse vegetation of the Sahara (see review in Hooghiemstra et al., 2006). In contrast, to the south of where cores with Cheno-Am-dominated pollen are situated, modern

\footnotetext{
* Corresponding author.

E-mail address: dmuhs@usgs.gov (D.R. Muhs).
} 

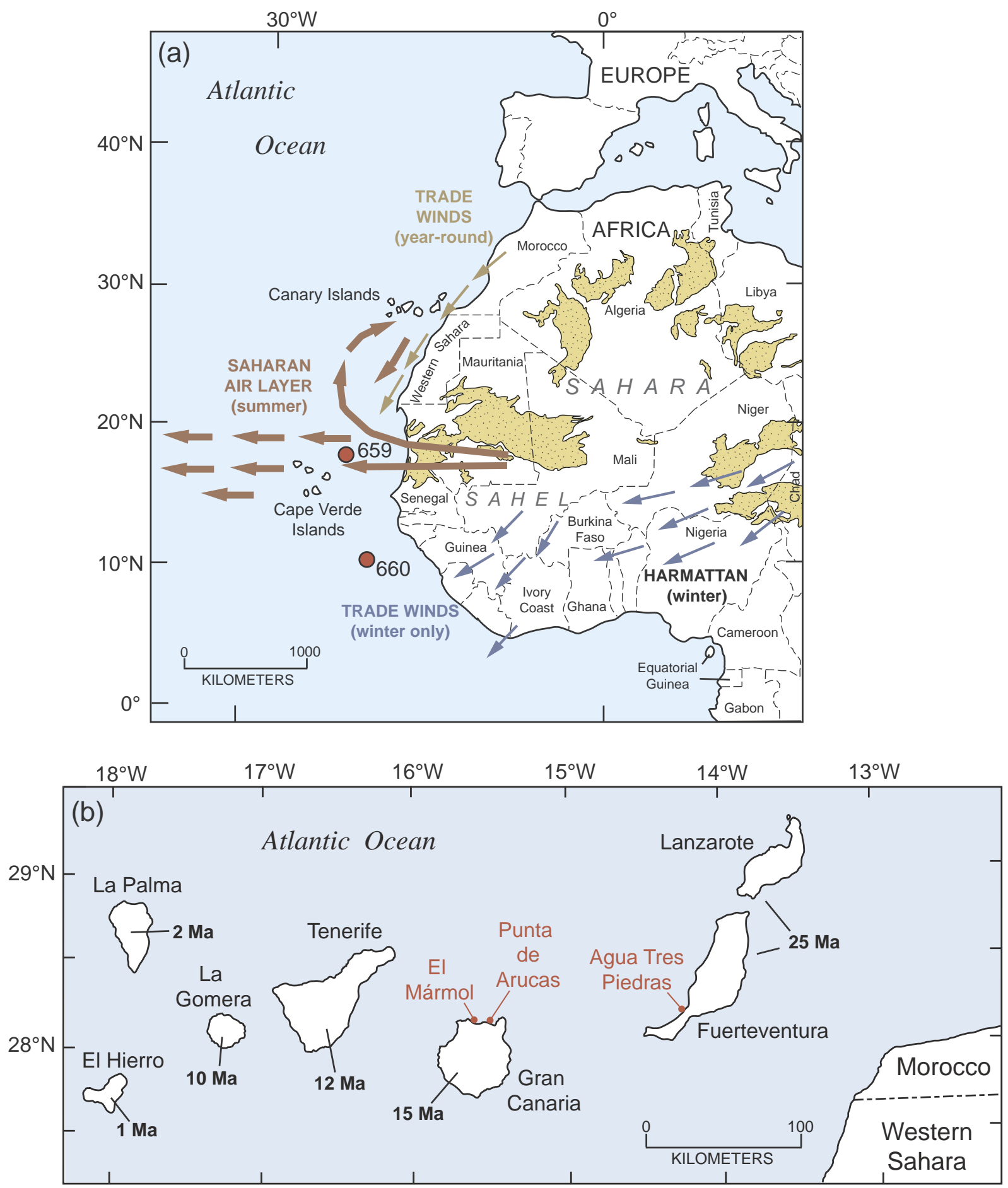

Fig. 1. (a) Map showing northwestern Africa, the Canary Islands study area, and the main dust-transporting winds and their seasons of transport. Dust-bearing wind paths and areas of major active sand seas (gold stippled areas) from sources in Muhs et al. (2010). Red circles indicate locations of Ocean Drilling Program (ODP) core sites. (b) Map of the Canary Islands, with ages of oldest exposed rocks given in bold type (from Guillou et al., 2004a, 2004b; Carracedo and Troll, 2016). Coordinates of study localities: Agua Tres Piedras, Fuerteventura: $28.18743^{\circ} \mathrm{N}, 14.25644^{\circ} \mathrm{W}$; El Mármol, Gran Canaria: $28.152389^{\circ} \mathrm{N}, 15.621237^{\circ} \mathrm{W}$; Punta de Arucas, Gran Canaria: $28.144405^{\circ} \mathrm{N}, 15.496473^{\circ} \mathrm{W}$. (For interpretation of the references to colour in this figure legend, the reader is referred to the web version of this article.)

samples extracted from young marine sediments are rich in Gramineae pollen, reflecting the dominant grassland vegetation of the more humid Sahel region. Older parts of cores taken off western Africa show continuous records of Cheno-Am (desert) vegetation going back to at least $\sim 650$ ka (Dupont et al., 1989). Aeolian transport of freshwater diatoms has also been utilized as an indicator of North African aridity, with records that go back to at least 3.8 Ma (Pokras and Ruddiman, 1989).
Because of its broad, low-elevation basins, abundant loose, finegrained, alluvial sediment, active dune fields, and lack of protective vegetation, the Sahara is, at present, the most important source of longrange-transported mineral dust in the world (see Prospero et al., 2002). Thus, other studies of deep-sea cores have utilized the sedimentological and mineralogical records found in marine sediments to document the transport of Saharan dust to the eastern Atlantic Ocean (Sarnthein et al., 


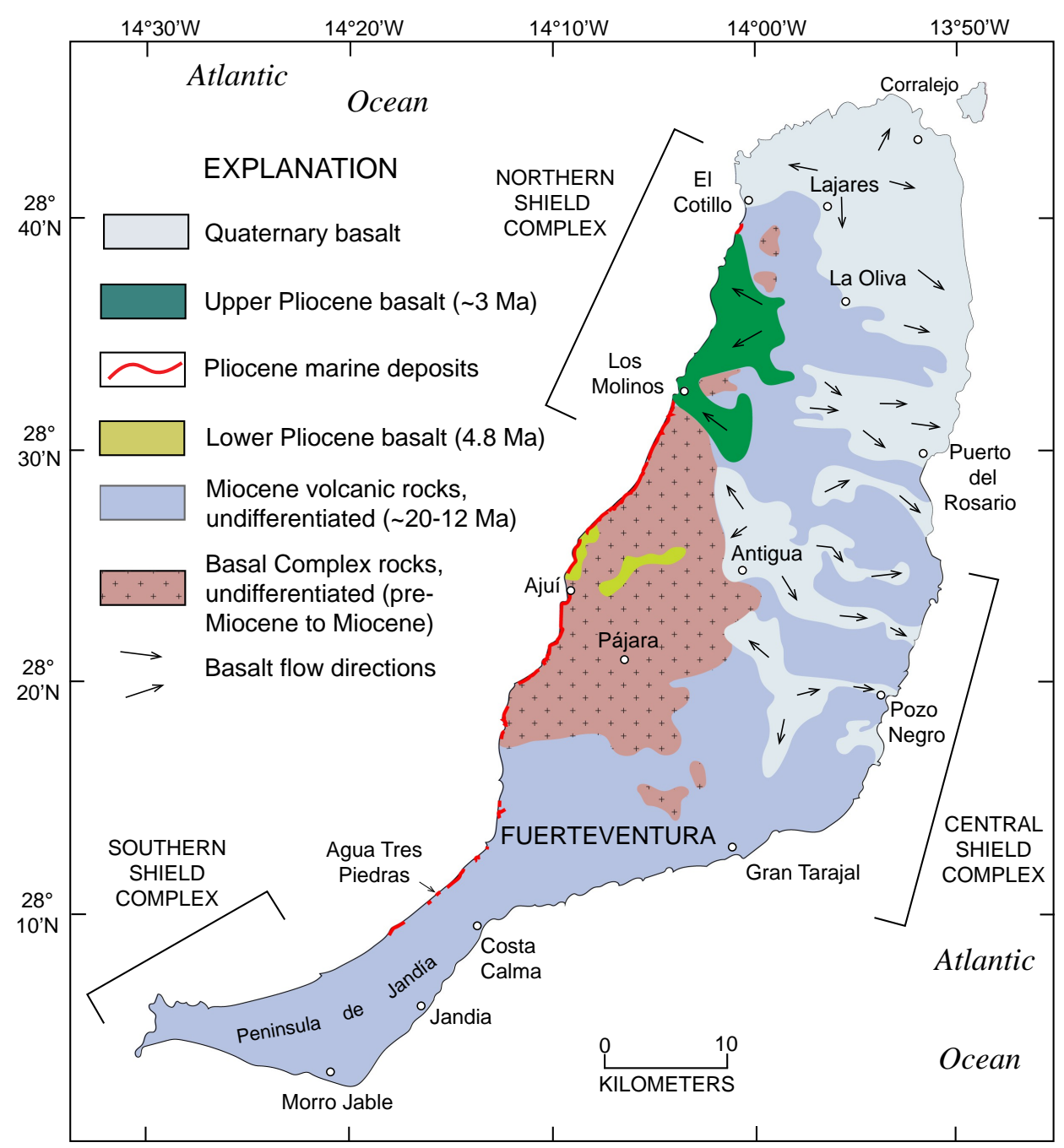

Fig. 2. Geologic map of Fuerteventura, redrawn from Balcells et al. (1991) and Meco et al. (2015) and location of Agua Tres Piedras study area. Also shown are the approximate areas of the three shield volcano complexes that make up the island (from Ancochea et al., 1996 and Carracedo and Troll, 2016, their Fig. 8.1).

1981, 1982; Thiede et al., 1982; Stein and Sarnthein, 1984; Ruddiman et al., 1989; Tiedemann et al., 1989; deMenocal, 1995; Pflaumann et al., 1998; Mulitza et al., 2008, 2010; Tjallingii et al., 2008; Skonieczny et al., 2019). As pointed out by Tiedemann et al. (1989), there are three main sources of clastic sediment found in cores off western Africa: (1) aeolian transport, (2) fluvial transport, and (3) turbidity currents. Of these, aeolian transport is considered to be the most important process for the origin of sediment in core locations well offshore. Deep-sea core investigations have, therefore, used sediment particle size (fine silts and clays), the presence of quartz and clay minerals (mica and kaolinite), and magnetic susceptibility (as a measure of hematite coatings on larger grains) as indicators of aeolian transport of dust from either the Sahara or Sahel to the eastern Atlantic Ocean. It should be noted, however, that even in offshore sites, a fluvial component has been recognized within the sediment population (e.g., Stein and Sarnthein, 1984, their Fig. 6). In addition, sand-sized mica, considered unlikely to be of aeolian origin, has been documented in a core $\sim 170 \mathrm{~km}$ off the northwestern African coast (Thiede et al., 1982, their Fig. 6). Van der Does et al. (2016, 2018), however, have recently documented aeolian transport of sand-sized particles to the open ocean, so the earlier finding of Thiede et al. (1982) may not necessarily exclude an aeolian origin for mica. Nevertheless, although studies of marine sediments have suggested a relatively great age (Pliocene or Miocene) for the Sahara, there are limitations on the interpretation of an African origin for what is thought to be the aeolian component of such sediments. Ruddiman et al. (1989, p. 467-468) urged caution in the inferences of sources of sediment off the African continental margin.

It is well established that the eastern Atlantic Ocean and the volcanic Canary Islands receive dust from both the Sahara and Sahel at present, from a variety of dust-transporting winds (Fig. 1a). African dust is reported as a component of modern soils on the Canary Islands (Muhs et al., 2010) and is also found in paleosols of Pleistocene age (Huerta et al., 2015; Muhs et al., 2016; Menéndez et al., 2019; Roettig et al., 2019). These studies have demonstrated the presence of an African dust component by identification of minerals exotic to the Canary Islands. By far the majority of rocks on the Canary Islands are basalts that erupted during the Tertiary shield-building stages of the islands (Fuster et al., 1968a, 1968b; Carracedo and Troll, 2016). A dominance of basalt is significant for studying oceanic islands as natural dust traps, because similar to oceanic volcanic rocks found elsewhere (Greenough et al., 2005), Canarian volcanic rocks have a mineralogy dominated by olivine, plagioclase, pyroxenes, magnetite, apatite, and nepheline (Fuster et al., 1968a, 1968b; Hoernle and Schmincke, 1993; Carracedo et al., 2002; Muhs et al., 2010; Tornare et al., 2016). In contrast, minerals that are common in long-rangetransported dust are typically derived from upper continental crustal rocks, and include quartz, mica, plagioclase, and K-feldspar, as well as carbonate minerals and phyllosilicate clay minerals (e.g., Glaccum and Prospero, 1980; Muhs, 2013). Thus, on volcanic islands such as the Canaries, the presence of upper-crust-derived minerals in soils, 


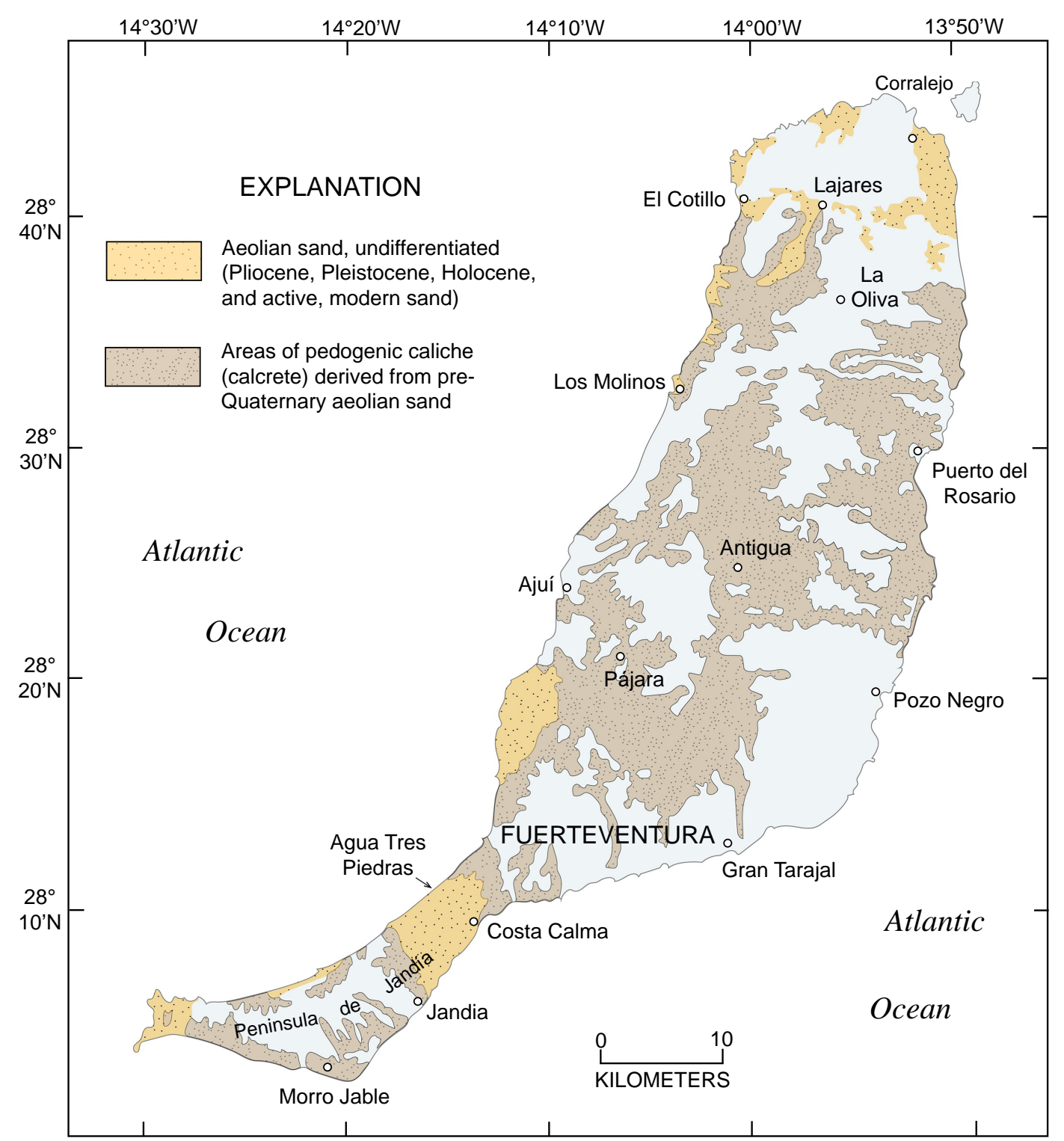

Fig. 3. Map of Fuerteventura, showing distribution of aeolian deposits and areas of pedogenic caliche (calcrete) derived from pre-Quaternary aeolian sand. Redrawn from Carracedo et al. (2005).

particularly quartz and mica, is exotic and can be interpreted to have an aeolian origin. Carracedo and Troll (2016) point out (p. 493) that with rare exceptions, quartz is largely absent in Canary Island volcanic rocks. One such exception is quartz that is found in some of the Mesozoic marine sediments of the "Basal Complex" (Fig. 2) on Fuerteventura (see Carracedo and Troll, 2016, p. 536), but such outcrops are of limited extent compared to the more voluminous basalts. On Gran Canaria, Jutzeler et al. (2010) reported that felsic volcanic rocks of Miocene age contain mica (biotite), but these rocks are found primarily on the southwestern half of the island, where fluvial systems drain to the southwest (Fig. 3). On the northeastern half of Gran Canaria, rocks are dominated by Pliocene and Quaternary rocks of mafic composition (Fuster et al., 1968b; Hoernle and Schmincke, 1993; Carracedo and Troll, 2016).

Following on the evidence for African-derived quartz in modern soils and Quaternary paleosols on the Canary Islands, this study tests the various hypotheses cited earlier for the age of the Sahara by examining the composition of Canarian paleosols ranging in age from early Pliocene to middle Pleistocene. The goal is to determine if paleosols of this age contain evidence of derivation, at least in part, from dust transported from Africa. We present mineralogical and geochemical data for Canary Islands paleosols found at three localities (see Figs. 2-4): (1) Fuerteventura, Agua Tres Piedras, also known as Istmo Jandía, paleosols of early Pliocene age (Meco et al., 2006, their Figs. 2.2 and 2.3; Meco et al., 2011, their Fig. 4); (2) Gran Canaria, El Mármol, of late Pliocene age (Meco et al., 2015, their Fig. 7c); and (3) Gran Canaria, Punta de Arucas, of middle Pleistocene age (Meco et al., 2011, their Fig. 9). We utilize mineralogical and geochemical data to ascertain the composition of the paleosols and compare these attributes with those of the local rocks and African dust.

\section{Methods}

Volcanic rocks, sediments, and paleosols from all localities were analyzed for both mineralogy and geochemistry as bulk samples after pulverization and homogenization. Mineralogy of bulk samples was determined by X-ray diffractometry (XRD) of randomly oriented mounts. For bulk analyses, quartz is identified by peaks at $20.9^{\circ}$ and $26.6^{\circ}$, two-theta (Moore and Reynolds Jr., 1997). From separate unpulverized splits, the clay $(<2 \mu \mathrm{m})$ fractions of paleosols were isolated 


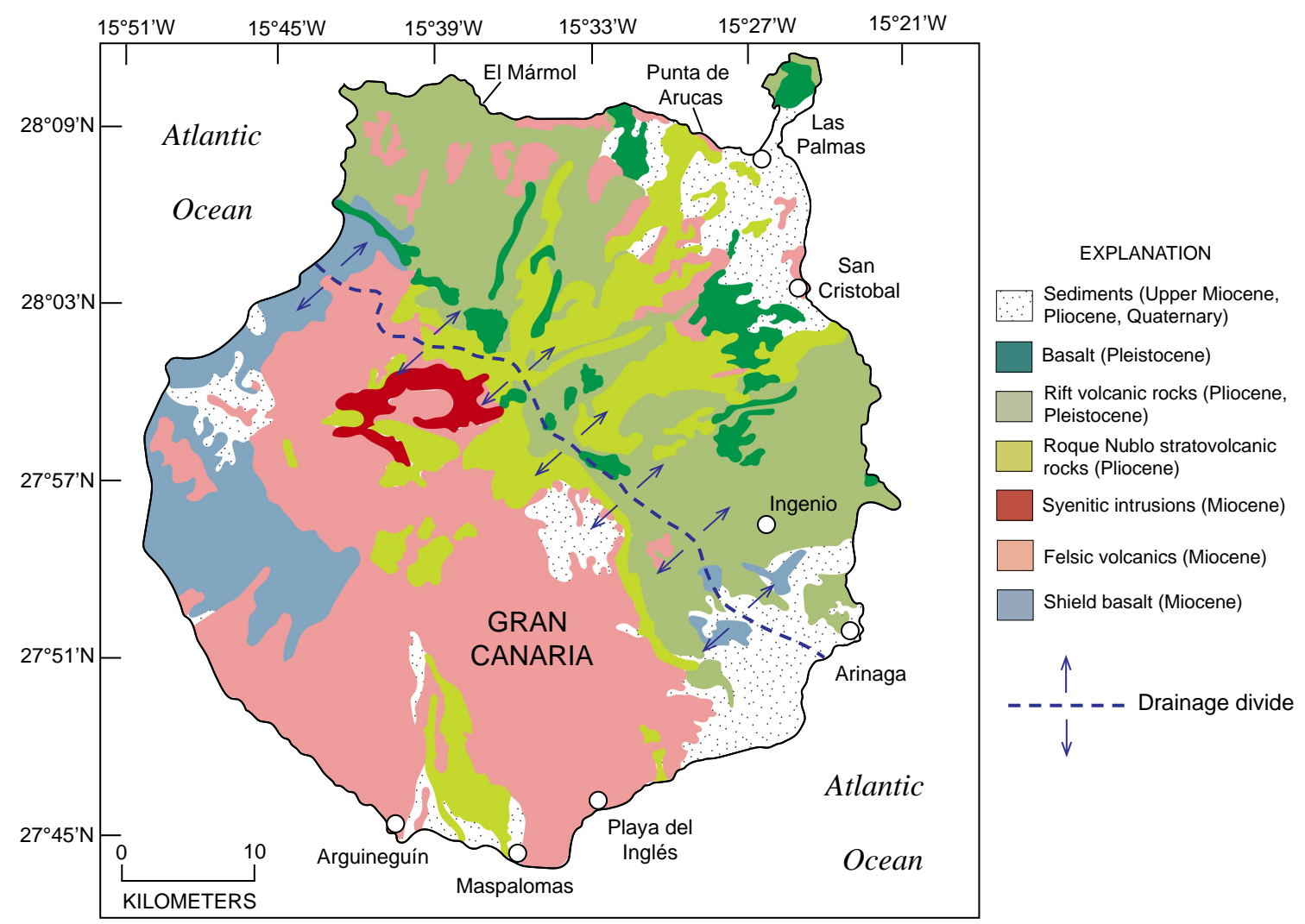

Fig. 4. Geologic map of Gran Canaria, redrawn from Carracedo and Troll (2016), which in turn was compiled from geologic maps of the island by Fuster et al. (1968b), Schmincke (1976), Balcells et al. (1992), and Carracedo et al. (2002). Note that the age range for the "Rift volcanic rocks" unit has been updated from Carracedo and Troll (2016) based on ${ }^{40} \mathrm{Ar} /{ }^{39} \mathrm{Ar}$ ages reported by Guillou et al. (2004b) and Meco et al. (2015).

by sedimentation after removal of organic matter and most or all carbonates. Mineralogy of the clay fraction was determined by XRD from three treatments: air-dry, glycolated, and heat-treated $\left(550^{\circ} \mathrm{C}\right.$ for $\left.1 \mathrm{~h}\right)$, all from oriented mounts. Clay mineral identifications follow guidelines in Moore and Reynolds Jr. (1997). Smectite has a prominent peak (001) at $\sim 5.2^{\circ}$ when glycolated and this peak collapses after heating to $550^{\circ} \mathrm{C}$ for $1 \mathrm{~h}$. Mica has peaks at $8.9^{\circ}(001), 17.7^{\circ}(002)$, and $26.6^{\circ}(003)$ when air-dry or glycolated and these peaks persist after heat treatment. Kaolinite has peaks at $12.5^{\circ}(001)$ and $24.9^{\circ}(002)$ when air-dry or glycolated and these peaks collapse after heat treatment. Chlorite is identified by peaks at $6.2^{\circ}(001)$ and $18.8^{\circ}(003)$ on heat-treated samples.

Major element geochemistry was determined by wavelength-dispersive X-ray fluorescence (XRF) on bulk samples after pulverization. Trace element geochemistry, including the rare earth elements (REE) was determined by instrumental neutron activation analysis (INAA), following methods in Budahn and Wandless (2002). All data are presented in the Supplementary Data Tables and can be found as a U.S. Geological Survey data release online (https://doi.org/10.5066/ P90FF7KF). Taylor and McLennan (1985) and Bhatia and Crook (1986) point out that ternary plots of certain trace elements are useful for distinguishing rocks or sediments derived primarily from mantle sources (such as Canary Islands basalts) versus upper continental crustal sources (such as African dust). Variables for these plots include abundances of Sc-Th-La, Co-Hf-Th, and Zr-Sc-Th. For identification of possible dust components within Canary Islands paleosols, we use similar ratios of trace elements that have been effective in identifying such components in modern Canary Island soils (Muhs et al., 2010). These ratios utilize trace elements with a minimum degree of mobility in near-surface environments (Taylor and McLennan, 1985; McLennan, 1989) and include Sc, La, Hf, Th, Cr, and Ta. Because Sc and $\mathrm{Cr}$ are enriched in pyroxenes in mafic volcanic rocks, soils or sediments derived from such sources will plot near Sc and Cr poles on ternary diagrams. In contrast, soils or sediments derived from upper continental crustal sources will plot near the $\mathrm{La}, \mathrm{Hf}$, Th, and Ta poles on such diagrams.

The REE are found in a broad range of minerals including pyroxenes, micas, chlorite, clay minerals, amphiboles, zircon, feldspars, and apatite (see summary tables in Taylor and McLennan, 1985). We use three sensitive indicators of REE composition, $\mathrm{La}_{N} / \mathrm{Yb}_{\mathrm{N}}, \mathrm{Gd}_{\mathrm{N}} / \mathrm{Yb}_{\mathrm{N}}$, and $\mathrm{Eu} / \mathrm{Eu}^{*}$, where the "N" subscript indicates the element concentration is normalized, by convention, to chondritic meteorite values (Mason and Moore, 1982). Well-mixed, far-traveled African dust has an overall REE composition similar to that of upper continental crust (Muhs et al., $2007,2010,2012$ ), which has an average $\mathrm{La}_{\mathrm{N}} / \mathrm{Yb}_{\mathrm{N}}$ value of $\sim 9$ (Taylor and McLennan, 1985). African dust samples collected on Barbados and Bermuda have $\mathrm{La}_{N} / \mathrm{Yb}_{\mathrm{N}}$ values ranging from $\sim 5$ to $\sim 13$ (Muhs et al., 2007, 2010, 2012). Unlike many mid-ocean ridge basalts, Canary Islands basalts of Quaternary and Tertiary age are enriched in La, and have $\mathrm{La}_{\mathrm{N}} / \mathrm{Yb}_{\mathrm{N}}$ values ranging from $\sim 12$ to $\sim 22$ on Lanzarote (Muhs et al., 2010), $\sim 14$ to $\sim 40$ on Gran Canaria (Aulinas et al., 2010) and $\sim 6$ to $\sim 29$ on Fuerteventura (Tornare et al., 2016). As a consequence, we also utilize another sensitive REE measure, $\left(\mathrm{Gd}_{N} / \mathrm{Yb}_{N}\right)$, which McLennan (1989) shows to be an effective discriminator in sediment provenance studies.

Rocks from the lower continental crust have positive Eu anomalies (Taylor and McLennan, 1985). In contrast, the upper continental crust (which has an average composition of granodiorite) is depleted in Eu, relative to Sm and Gd, on a chondrite-normalized REE plot, a condition referred to as a negative Eu anomaly. Mantle-derived rocks, such as island hotspot basalts or mid-ocean ridge basalts, typically have neither positive or negative Eu anomalies.

The sign and degree of any Eu anomaly can be quantified by the $\mathrm{Eu} /$ $\mathrm{Eu}^{*}$ value, where $\mathrm{Eu}$ is the chondrite-normalized $\mathrm{Eu}$ concentration 


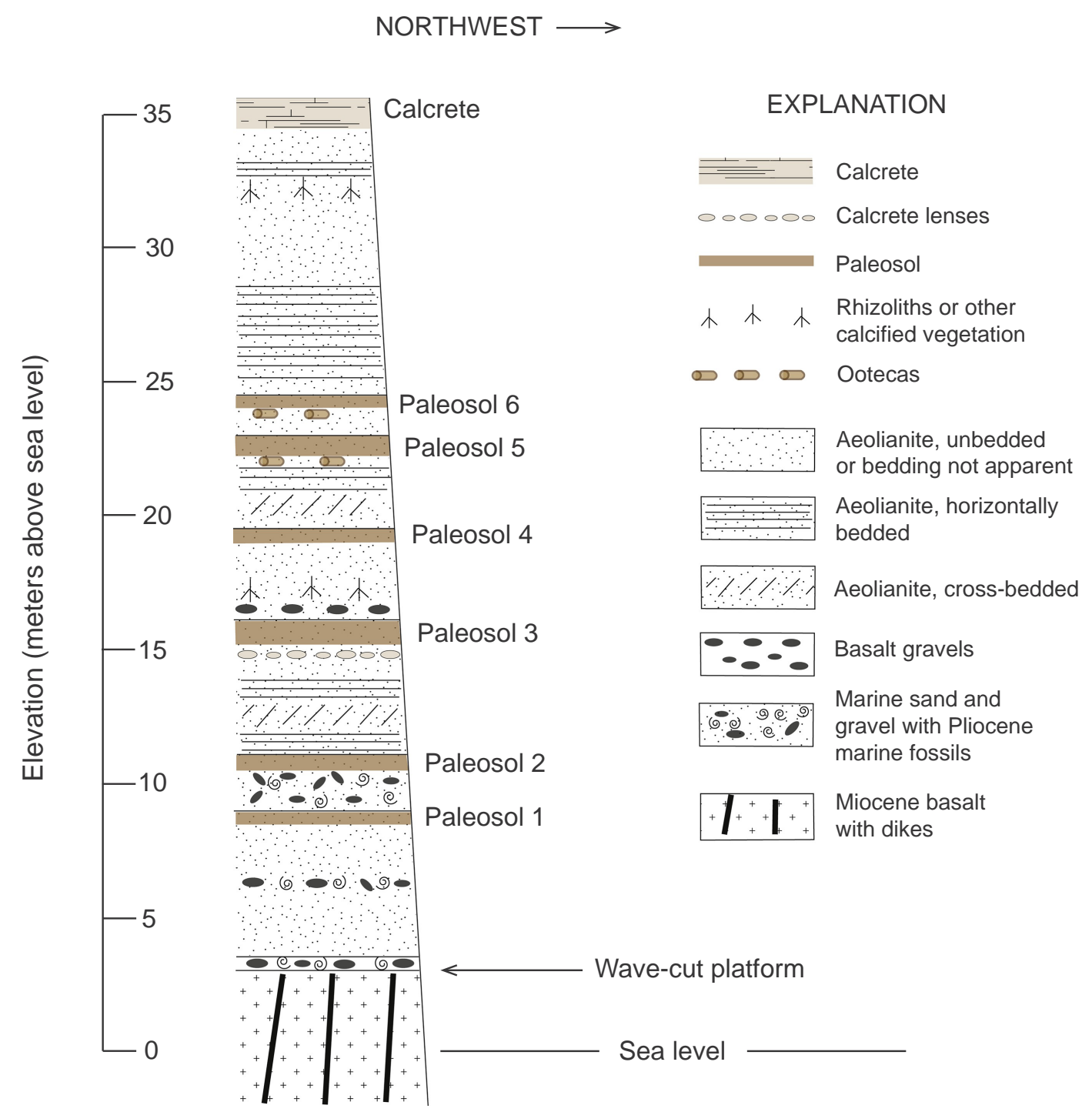

Fig. 5. Stratigraphy exposed in cliff section at Agua Tres Piedras, Fuerteventura (see Figs. 2, 4 for location). Paleosols sampled for mineralogy and geochemistry are numbered 1-6, from oldest to youngest. Pliocene fossils include Nerita emiliana and Patella ambroggi (found in lowest marine sand, immediately above the Miocene basalt; in marine sand and gravel below paleosol 1; and in marine sand and gravel unit between paleosols 1 and 2; see Meco et al., 2015, 2016). "Ootecas" below paleosols 5 and 6 are trace fossils of the African-derived Moroccan locust Dociostaurus maroccanus (Meco et al., 2011).

$\left(\mathrm{Eu}_{\mathrm{N}}\right)$, and $\mathrm{Eu}^{*}$ is $\left(\mathrm{Sm}_{\mathrm{N}} \times \mathrm{Gd}_{\mathrm{N}}\right)^{0.5}$. Basalts that reflect a dominantly mantle origin, as mentioned above, typically have no Eu anomaly and therefore have $\mathrm{Eu} / \mathrm{Eu}^{*}$ values of 1.0 (see examples in Budahn and Schmitt, 1985 [Hawaii] and Muhs et al., 2010 [Canary Islands]). Values $<1.0$ indicate "negative" Eu anomalies; values $>1.0$ indicate "positive" Eu anomalies. Because igneous rocks of the upper continental crust typically have negative Eu anomalies, sedimentary rocks and sediments (such as dust) derived from such rocks have $\mathrm{Eu} / \mathrm{Eu}^{*}$ values ranging from 0.5 to 0.6 to just under 1.0 (Taylor and McLennan, 1985; McLennan, 1989). Plots of $\mathrm{La}_{\mathrm{N}} / \mathrm{Yb}_{\mathrm{N}}$ vs. $\mathrm{Eu} / \mathrm{Eu}^{*}$ are powerful tools for identifying dust components in soils where mafic volcanic rocks, such as basalts, are the competing parent material (Muhs et al., 2007, 2010, 2012).

\section{Results}

\subsection{Geology of Fuerteventura and stratigraphy of Agua Tres Piedras}

Basalts that were generated during the building of three Tertiary shield volcano complexes (Fig. 2) dominate the island of Fuerteventura (Coello et al., 1992; Carracedo and Troll, 2016). Thus, much of the island is composed of volcanic rocks of Miocene ("Series I" of Fuster et al., 1968a), Pliocene ("Series II"), Pleistocene ("Series III"), and Holocene ("Series IV") age. An exception to this is the area referred to as the "Basal Complex", which consists of a wide variety of rocks, ranging in age from pre-Miocene to Miocene. In addition to volcanic rocks, however, carbonate-rich surficial deposits cover much of Fuerteventura. Some of these are areas of active, Holocene, Pleistocene, or Pliocene aeolian sand, but even larger areas are covered by pedogenic calcretes (caliche) derived from pre-Quaternary aeolian sand (Fig. 3). Carracedo et al. (2005) and Meco et al. (2006) reported that during the late Miocene $(\sim 6-5 \mathrm{Ma})$ an equatorial oceanic climate dominated the waters around the Canary Islands. Bioclastic sands, derived from a tropical marine invertebrate fauna, accumulated on the insular shelves of the islands at this time. In the Pliocene, there was regional cooling, establishment of the cold Canary Current, and initiation of the trade winds. During one or more marine regressions, bioclastic sands that had been accumulating on the insular shelves were then blown into dunes onto the islands. With their high carbonate content, many of these windblown sediments were cemented into aeolianite. This model of aeolianite formation is similar to that proposed for the California Channel Islands, during interglacial-glacial cycles of the Quaternary 


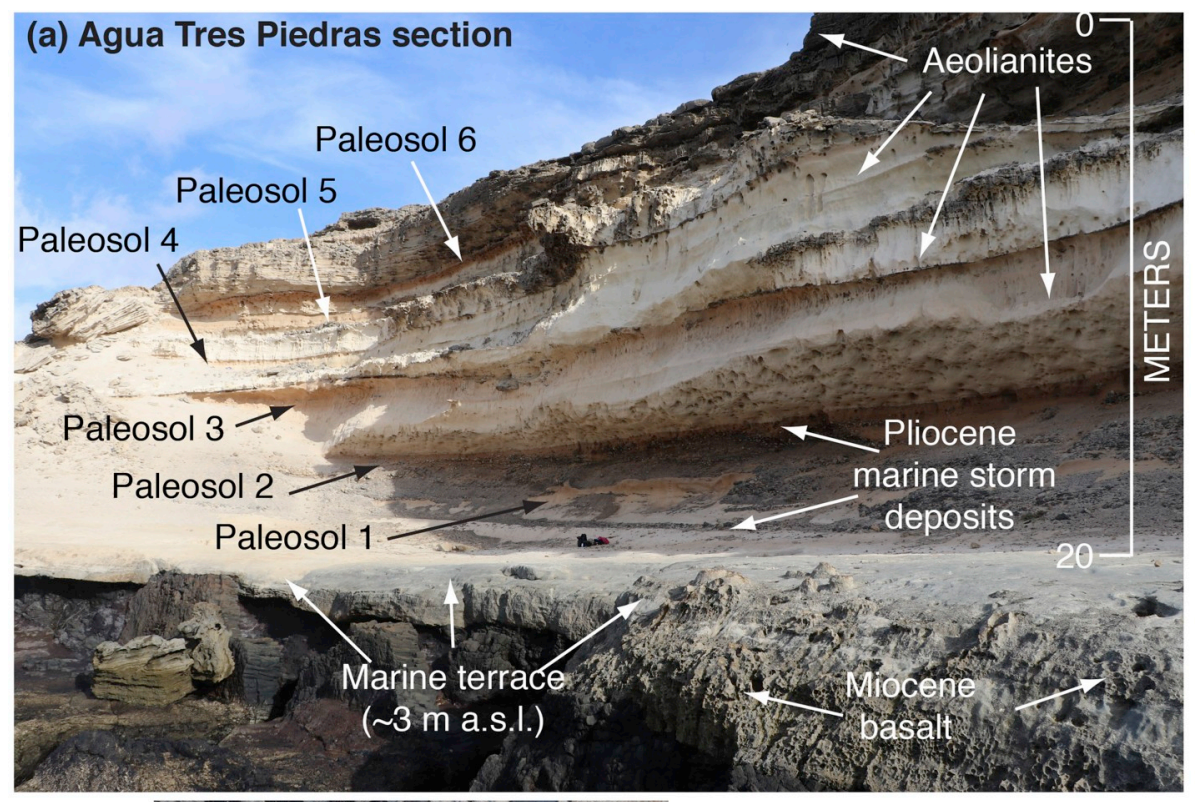

Fig. 6. (a) Sea cliff exposure of Agua Tres Piedras study area, southern Fuerteventura (Meco et al., 2005, 2011), showing Miocene basalt, wave-cut bench on basalt, sands and gravels interpreted to be storm deposits (containing the extinct marine mollusks Patella ambroggii and Nerita emiliana), aeolianites, and intercalated paleosols. Basalt age from Coello et al. (1992); see also Meco et al. (2015). (b) Close-up of marine deposits resting on wave-cut bench, with Patella ambroggii fossils and basalt clasts. Knife for scale is $5.5 \mathrm{~cm}$ long. (c) Close-up of marine mollusks Patella ambroggii and Nerita emiliana collected from marine storm deposits underlying " $\mathrm{Pa}$ leosol 1" shown in (a). Photographs by D.R. Muhs.

(b)

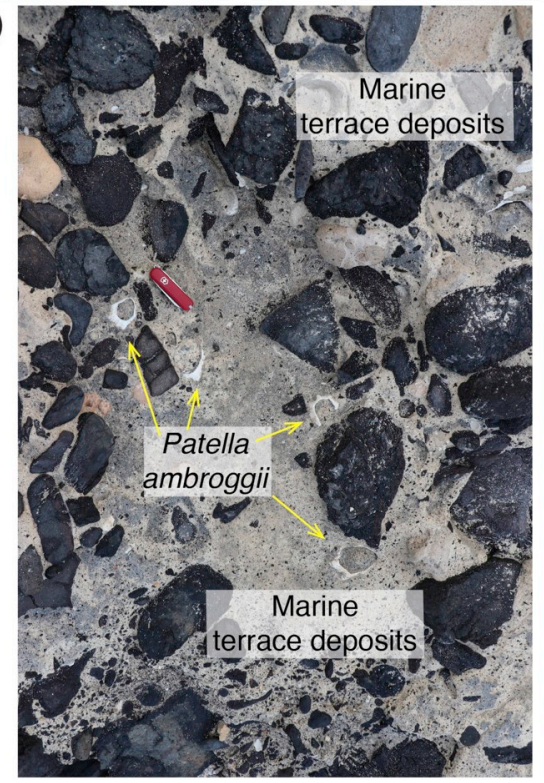

(c)

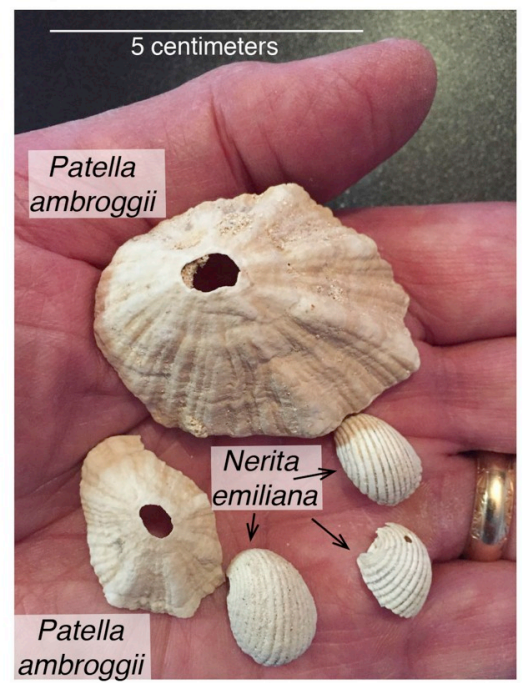

(Muhs et al., 2018). Deposition of the carbonate sands on the Canary Islands was intermittent, as evidenced by the presence of numerous paleosols intercalated between aeolian sand beds (Meco et al., 2006). At some point in the Pliocene, much of this aeolian sand was stabilized and a well-developed calcrete ("caliche," soil "K horizon," or petrocalcic horizon) formed. Periodically, parts of the calcrete were eroded and sand-sized fragments were transported to other parts of the islands, forming younger, carbonate-rich aeolian sand beds, augmented by new inputs of marine bioclastic sands during sea-level regressions of the Quaternary. Thus, much of the surface of Fuerteventura has a mantle of calcareous sand, derived either from bioclastic sand or reworked from calcrete derived from older episodes of bioclastic sand deposition (Fig. 3).

At Agua Tres Piedras (Figs. 2, 3), also referred to as the Istmo de Jandía locality in Meco et al. (2006, 2011), we examined a 32-m-thick sequence of marine deposits and carbonate aeolianites. The base of the section is a wave-cut bench truncating Miocene ( $15-14$ Ma; see Coello et al., 1992) basalt, overlain by marine gravels and fossils (Figs. 5, 6a). Elsewhere on the western coast of southern Fuerteventura, similar marine deposits, $\sim 3-5 \mathrm{~m}$ above sea level, have been mapped over a shore-parallel distance of at least $10 \mathrm{~km}$ (Meco et al., 2007). Above these marine deposits are two additional marine beds, composed of carbonate sand and basaltic gravel, interpreted to be storm deposits. The older marine terrace deposits on basalt and the younger marine storm deposits above them contain the fossil gastropods Patella ambroggii and Nerita emiliana (Figs. 6b, c). Above the storm deposits are five carbonate aeolianites, part of the carbonate blanket that covers much of the island (Fig. 3). Some of these aeolianites are cross-bedded, with others exhibiting horizontal bedding. The aeolianites may have accumulated as climbing dunes or "sand ramps." Thus, as is the case with many climbing dunes, coarse clasts of basalt are present in some of the aeolianite units and are interpreted to be alluvial-colluvial deposits mixed with the wind-blown sands. Six paleosols, numbered 1 (oldest) to 6 (youngest) are intercalated within the marine and aeolianite units (Figs. 6a, 7) and the entire section is capped with a $\sim 1.1$-m-thick laminar calcrete. The buried paleosols are found in the $\sim 20 \mathrm{~m}$ of section above the oldest marine deposits and are recognizable by their higher silt and clay contents and their pink (7.5YR $7 / 3$ or $8 / 3$, dry) or pinkish white (7.5YR $8 / 2$, dry) B horizons. The paleosol colors contrast with the bright, white (2.5Y $8 / 1$ or 10YR $8 / 1$, dry) colors of the aeolianite and marine carbonate sands. The interpretation of these zones as paleosols is supported by the observation that they have gradual lower 
(a)

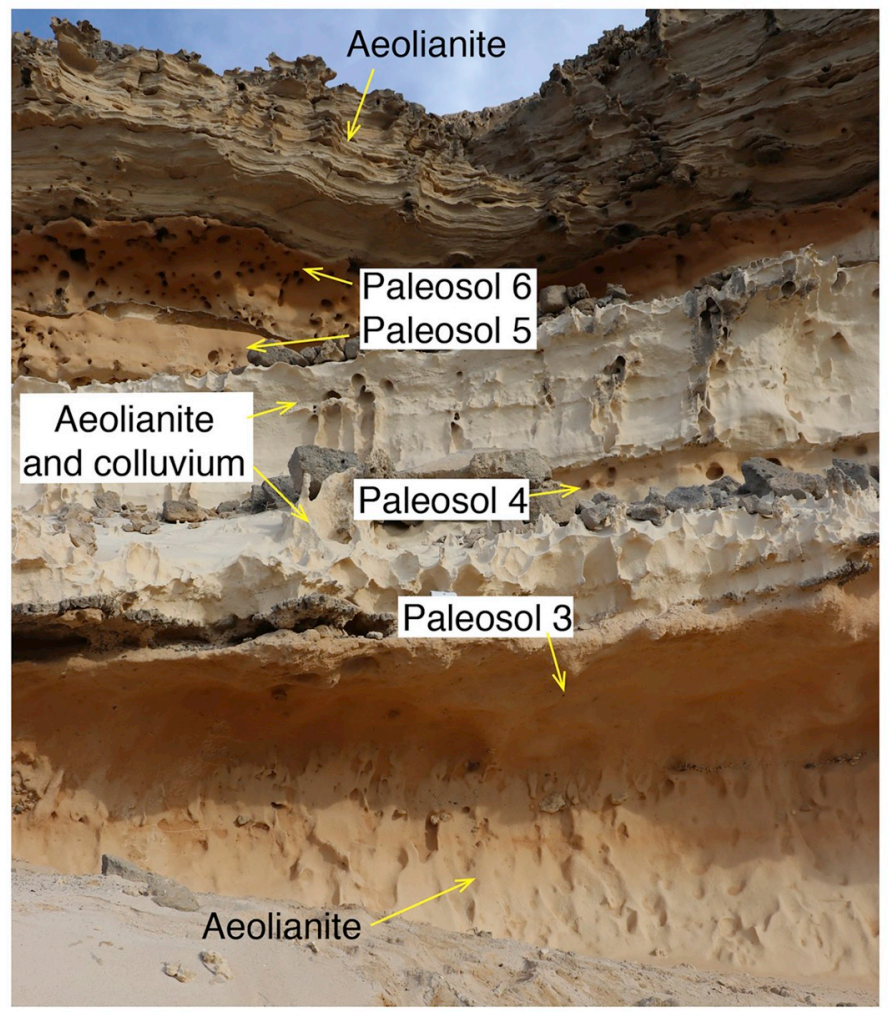

(b)

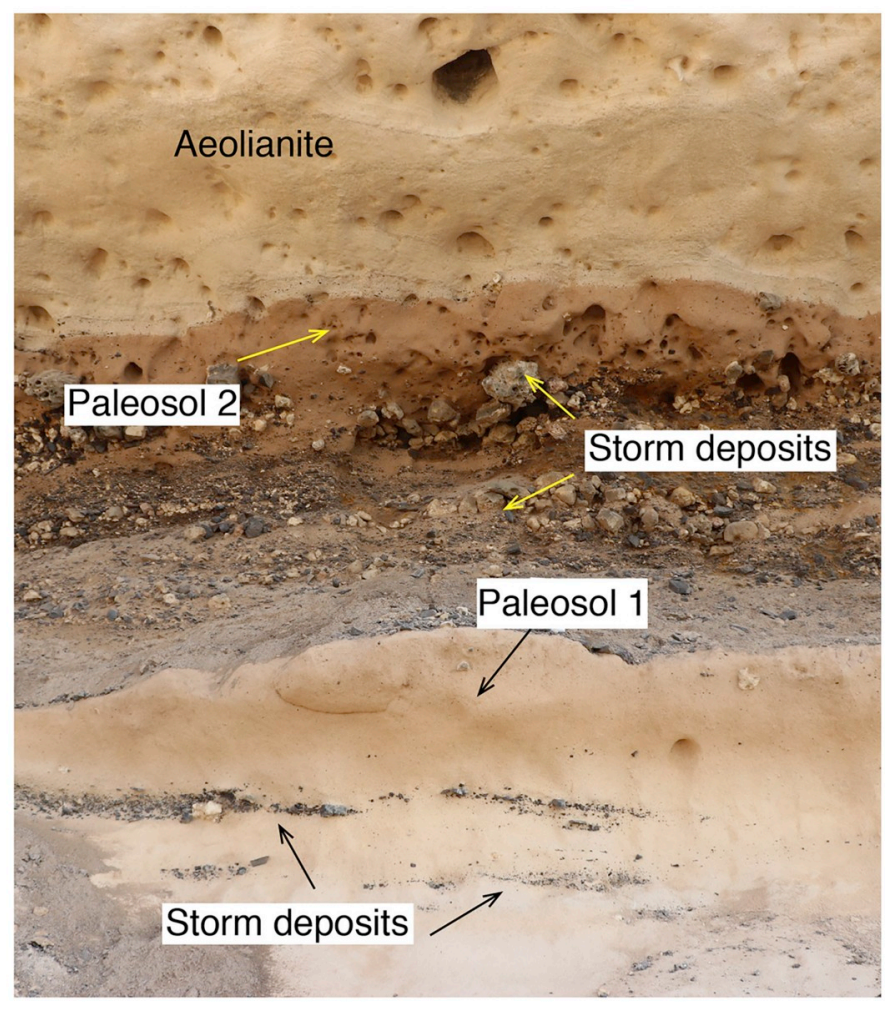

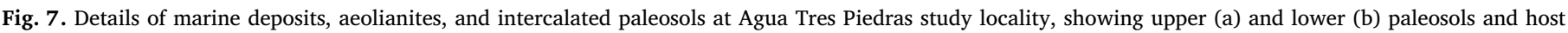
sediments. Note sharp upper contacts and gradual lower contacts of paleosols with superjacent and subjacent deposits, respectively. Photographs by D.R. Muhs.

boundaries with their host sediments, typical of modern soils, and sharp contacts with overlying deposits (Fig. 7). The lower parts of the youngest two buried paleosols (paleosols 5 and 6) contain "ootecas", which are trace fossils of the African-derived Moroccan locust Dociostaurus maroccanus (Meco et al., 2011).

The age of the entire section at Agua Tres Piedras is constrained by paleontology and dated volcanic flows. The fossil mollusks Patella ambroggii and Nerita emiliana (Figs. 6b, c) are extinct species and are not known to occur in deposits younger than the early Pliocene (Meco and Stearns, 1981; Meco et al., 2007, 2016). Because the marine terrace deposits and the two overlying storm deposits contain these taxa, these sediments are likely no younger than early Pliocene ( $\sim 5.3-3.6 \mathrm{Ma})$ age, assuming no reworking. The same marine/aeolianite sequence has been recognized farther north on the west coast of Fuerteventura (Fig. 2), between Ajuí $\left(28.4010^{\circ} \mathrm{N}, 14.1554^{\circ} \mathrm{W}\right)$ and Los Molinos $\left(28.5438^{\circ} \mathrm{N}\right.$, $14.0633^{\circ} \mathrm{W}$ ). Near Ajuí, similar marine deposits are overlain (discontinuously) by basalt dated to $\sim 5.0-4.8 \mathrm{Ma}$; at Los Molinos, the younger aeolianite sequence is overlain (also discontinuously) by a basalt flow dated to $\sim 2.8 \mathrm{Ma}$ (Meco et al., 2015; Carracedo and Troll, 2016, their Fig. 8.31; Betancort et al., 2016, their Figs. 3, 5). Thus, we consider the marine/aeolianite package at Agua Tres Piedras to date between $\sim 4.8 \mathrm{Ma}$ and $\sim 2.8 \mathrm{Ma}$. If this interpretation is correct, then all the paleosols exposed at this locality formed in the Pliocene.

\subsection{Gran Canaria: geology and stratigraphy of the study sites}

In contrast to Fuerteventura, Gran Canaria (Fig. 4) has a diversity of Tertiary volcanic rocks, with compositions varying from basalt to phonolite, trachyte, and rhyolite (Fuster et al., 1968b; Hoernle and Schmincke, 1993; Carracedo and Troll, 2016). The southwestern part of the island is dominated by volcanic rocks with a felsic composition. In contrast, the northeastern half of the island, where we conducted our studies, is composed primarily of mafic rocks of Pliocene-Quaternary age, the majority of which are nephelinites, tholeiites, basanites, and alkali basalts (Hoernle and Schmincke, 1993). The contact between the dominantly felsic rocks of the southwestern part of the island and the mafic rocks of the northeastern half of the island corresponds roughly to the major drainage divide as well. Near the contact, streams that dissect the felsic rocks drain to the southwest, whereas streams that dissect the mafic rocks drain to the northeast (Fig. 4).

On northeastern Gran Canaria, we studied a paleosol, nearly a meter thick, at a locality called El Mármol (Figs. 1b, 4), where a sea cliff exposes lava flows that are $\sim 120 \mathrm{~m}$ thick (Fig. 8). The paleosol, first noted by Meco et al. (2015), is found within the upper part of a cliff section at a depth of $\sim 9.5 \mathrm{~m}$. It is recognizable by its light brown (7.5YR 6/4, dry), pink (7.5YR 7/4, dry), or reddish yellow (7.5YR 6/6, dry) Bw and Bt horizons, high clay content, and distinctive clay films on ped faces. Although the A horizon is missing, the overall B horizon thickness is $\sim 90 \mathrm{~cm}$. The overlying and underlying basaltic lavas have both been dated to $\sim 3.0-2.9 \mathrm{Ma}$ (Guillou et al., 2004b).

We also studied a mid-Quaternary paleosol on Gran Canaria at Punta de Arucas (Figs. 1b, 4), developed on Pleistocene basalt. This rock is a pillow lava, indicating submarine deposition, and K/Ar ages of $402 \pm 20 \mathrm{ka}$ and $442 \pm 22 \mathrm{ka}$ have been reported by Meco et al. (2002). The lava was extruded from the nearby Cardones volcano. This Pleistocene lava is underlain by phonolite of Miocene age. At the seacliff exposure we studied, the soil rests on the Pleistocene basalt, but inland of the sea cliff, the same soil is found overlying the Miocene phonolite. Along the coast in this area, the paleosol is overlain by highly fossiliferous marine sands and gravels, correlated to the $\sim 400 \mathrm{ka}$ Pleistocene high-sea stand of marine isotope stage (MIS) 11 by Meco et al. (2002). Correlative deposits on the island of Lanzarote have been directly dated by U-series methods and support this age assignment (Muhs et al., 2014). Thus, the paleosol exposed on the sea cliff formed 


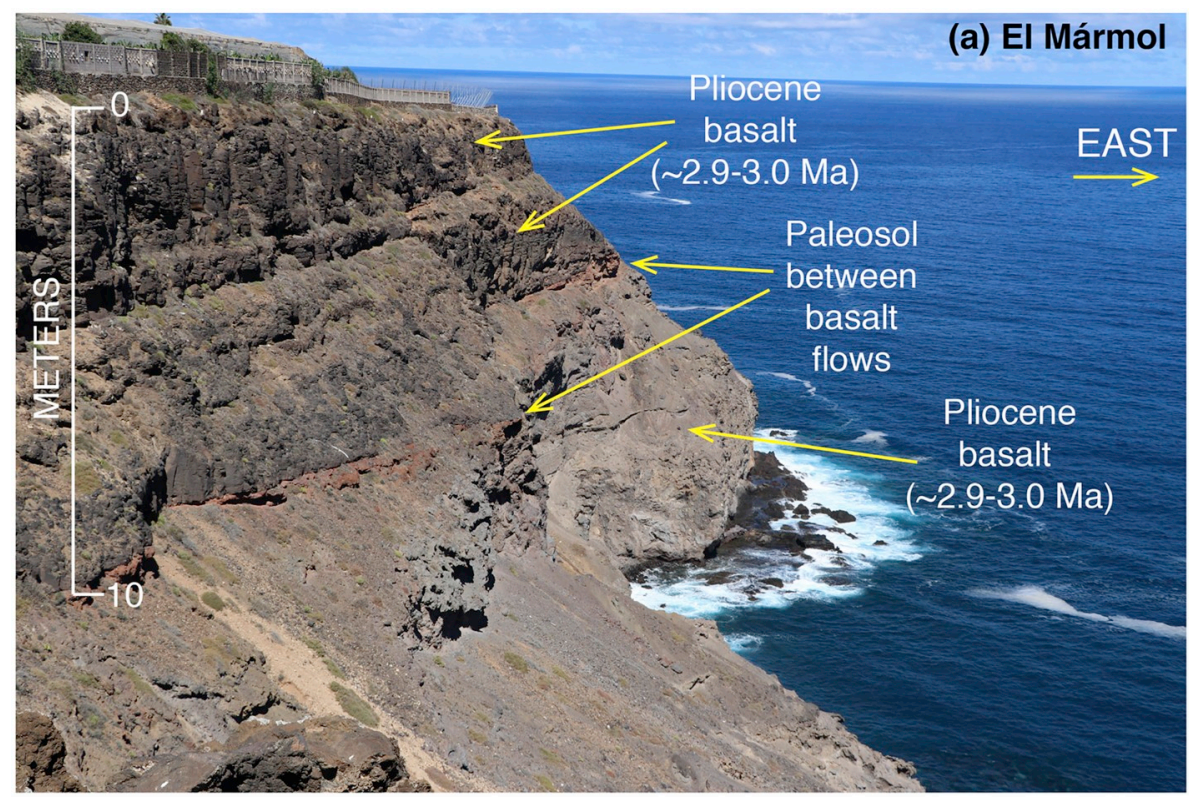

\section{(b) El Mármol}

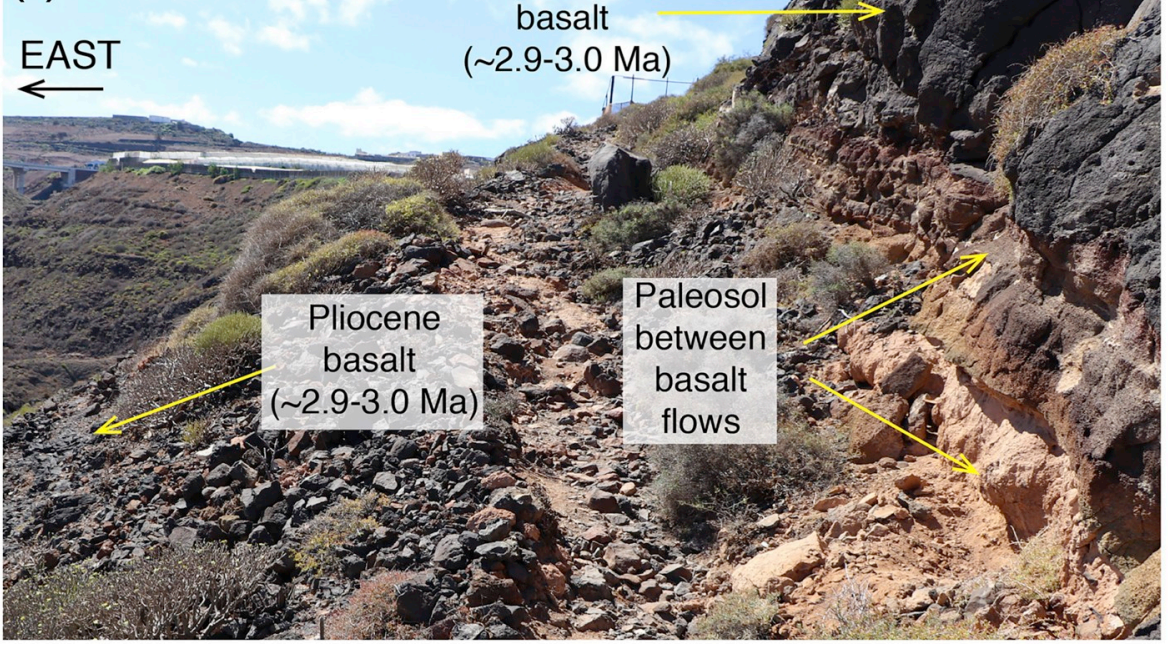

Fig. 8. El Mármol study locality, showing late Pliocene basalts (ages from Guillou et al., 2004b) and intercalated paleosol. Photographs by D.R. Muhs.

sometime after basalt was extruded from the Cardones volcano, but before the MIS 11 sea-level rise at $\sim 400 \mathrm{ka}$. The paleosol is $\sim 110 \mathrm{~cm}$ thick, characterized by a pink (7.5YR 7/4, dry), clay-rich Bt horizon, with a thin calcrete $\sim 30 \mathrm{~cm}$ below the top of the soil (Fig. 9a). The lower part of the soil hosts abundant ootecas, locust trace fossils (Fig. 9b), similar to those described above for Fuerteventura.

\subsection{Mineralogy and major element geochemistry of paleosols at Agua Tres} Piedras, Fuerteventura

At Agua Tres Piedras, marine sands that host the lower two paleosols and aeolianites that host the upper four paleosols are dominated by calcite and dolomite, with lesser amounts of plagioclase (most samples), and small amounts of halite, based on bulk XRD. The dominance of calcite and dolomite in these sediments is reflected in the high abundances of $\mathrm{CaO}+\mathrm{MgO}+\mathrm{LOI}$ (loss on ignition), a geochemical proxy for calcite and dolomite content. By this measure, carbonate mineral content in the marine sands and aeolianites ranges from $\sim 89 \%$ to $\sim 96 \%$ (Fig. 10).

The presence of paleosols is indicated not only by their distinctive colors and textures, apparent in the field, but also by the lower amounts of total carbonate (Fig. 10). As is the case with their host sediments, the paleosols contain calcite, dolomite, plagioclase and halite, based on bulk XRD analyses. In addition, however, most horizons of the paleosols and two of the uppermost aeolianites contain quartz (indicated by a "Q" in Fig. 10). Some horizons of the paleosols also contain gypsum.

Numerous studies have shown that much of the dust leaving the African continent by wind transport at present is extremely fine grained. Much of this dust consists of particles $<10 \mu \mathrm{m}$ in diameter and a substantial portion of that consists of particles with diameters $<2 \mu \mathrm{m}$, or clay-sized (see Chester et al., 1972, Guieu et al., 2002, and Stuut et al., 2005 for examples). By the time African dust reaches the Caribbean, $40-60 \%$ of the sediment mass may consist of particles $<2 \mu \mathrm{m}$ diameter, based on an early study (Prospero et al., 1970), although dust trap methods used at that time were somewhat biased towards finer grain sizes. Nevertheless, long-range-transported dust contains abundant fine grains $(<2 \mu \mathrm{m})$ and it is critical to examine this fraction within the paleosols.

Within this clay-sized $(<2 \mu \mathrm{m})$ fraction, all horizons of all paleosols at Agua Tres Piedras have smectite, mica, and kaolinite (Fig. 11). It is possible that the paleosols also contain clay-sized quartz, but the main quartz peak at $26.6^{\circ}$ is coincident with the mica (003) peak. In mica- 

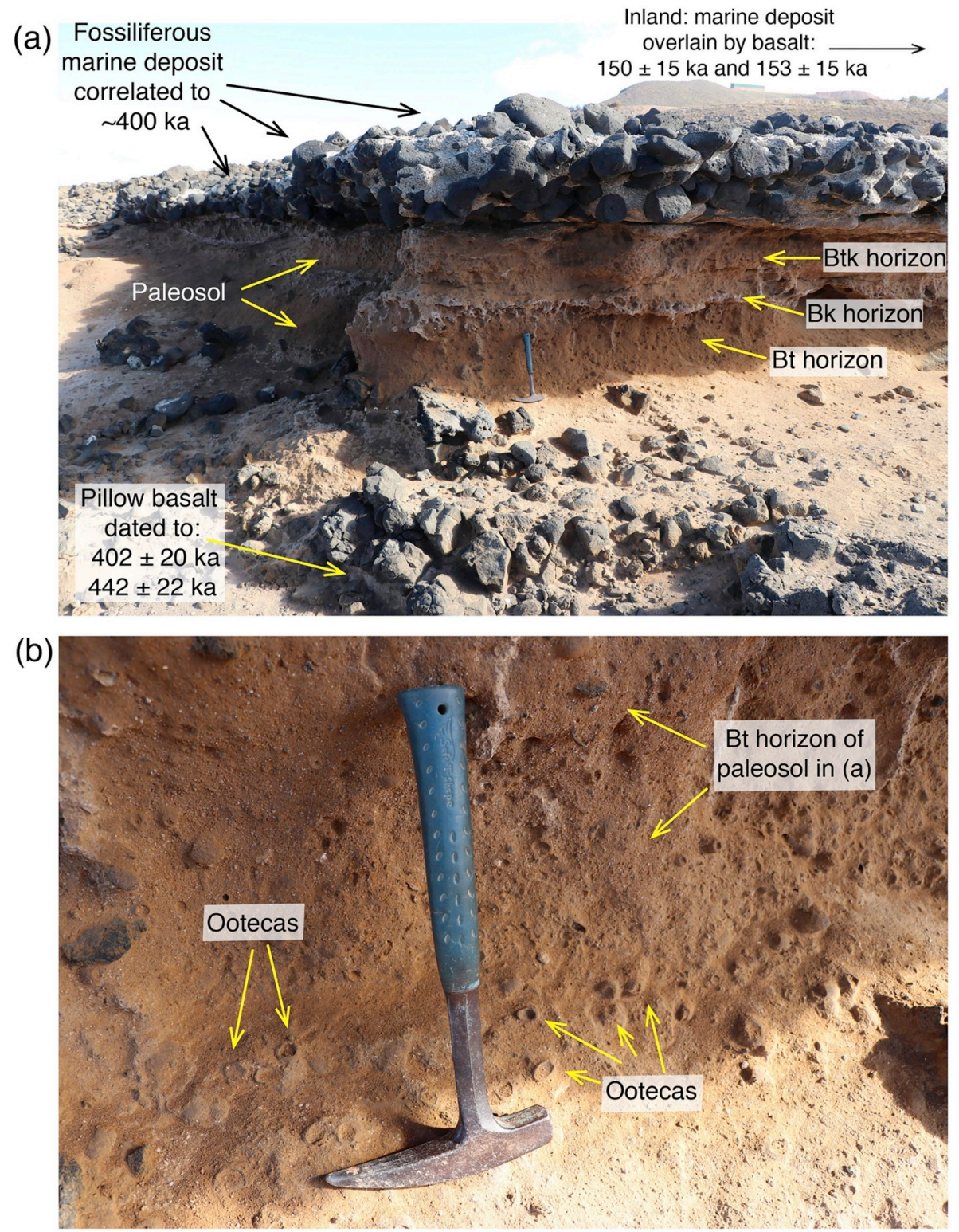

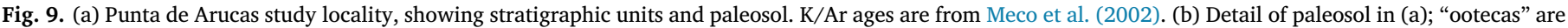

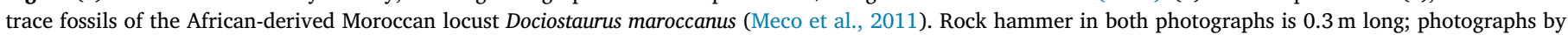
D.R. Muhs.

bearing sediments with an absence of quartz, the $8.9^{\circ}(001)$ mica peak is typically higher than the $26.6^{\circ}$ (003) mica peak (Moore and Reynolds, 1997). However, the heights of the peaks at $26.6^{\circ}$ in many of the paleosols studied here are higher than the $8.9^{\circ}$ mica peaks. Thus, the higher $26.6^{\circ}$ peak in these paleosols suggests the presence of some claysized quartz as well as mica. Within most of the paleosols, bulk values of $\mathrm{K}_{2} \mathrm{O} / \mathrm{TiO}_{2}$ are higher than those of local basalt and gabbro of Tertiary or older age on Fuerteventura (especially in paleosols 4, 5, and 6), consistent with the presence of mica (Fig. 12). Most horizons of paleosols 4, 5, and 6 have $\mathrm{K}_{2} \mathrm{O} / \mathrm{TiO}_{2}$ values that fall within the range of that reported for modern African dust (McTainsh and Walker, 1982; Wilke et al., 1984; Stuut et al., 2005).

\subsection{Mineralogy and major element geochemistry of paleosols on Gran Canaria}

At El Mármol on Gran Canaria, XRD analyses of whole-rock samples show that basaltic lapilli samples above the paleosol contain plagioclase, pyroxene, magnetite, nepheline, a zeolite mineral, and likely apatite. In basalts found below the paleosol at El Mármol, plagioclase, pyroxene, magnetite, nepheline, and a zeolite mineral are found, and apatite is also likely present. Mica is also present, but we are not confident that this mineral is derived from the basalt, as our field experience has shown that many outcrops of basalt on the Canary Islands are contaminated with mica-bearing dust.

In contrast, the paleosol at El Mármol contains, in bulk XRD analyses, quartz, mica, and plagioclase in almost all horizons (Fig. 13). Two horizons also contain calcite. The clay mineralogy of the paleosol at El Mármol is dominated by smectite, mica, and kaolinite in all horizons (Fig. 14), similar to the paleosols at Agua Tres Piedras. Also similar to Agua Tres Piedras, the relatively high $26.6^{\circ}$ peak suggests the possibility of some clay-sized quartz in the paleosol. Where quartz (from bulk analyses) is found in soil horizons at El Mármol, there are also complementary elevations in $\mathrm{SiO}_{2} / \mathrm{TiO}_{2}$ values, and where the presence of mica is confirmed, there are higher values of $\mathrm{K}_{2} \mathrm{O} / \mathrm{TiO}_{2}$ compared to the overlying and underlying basalt (Fig. 13). 


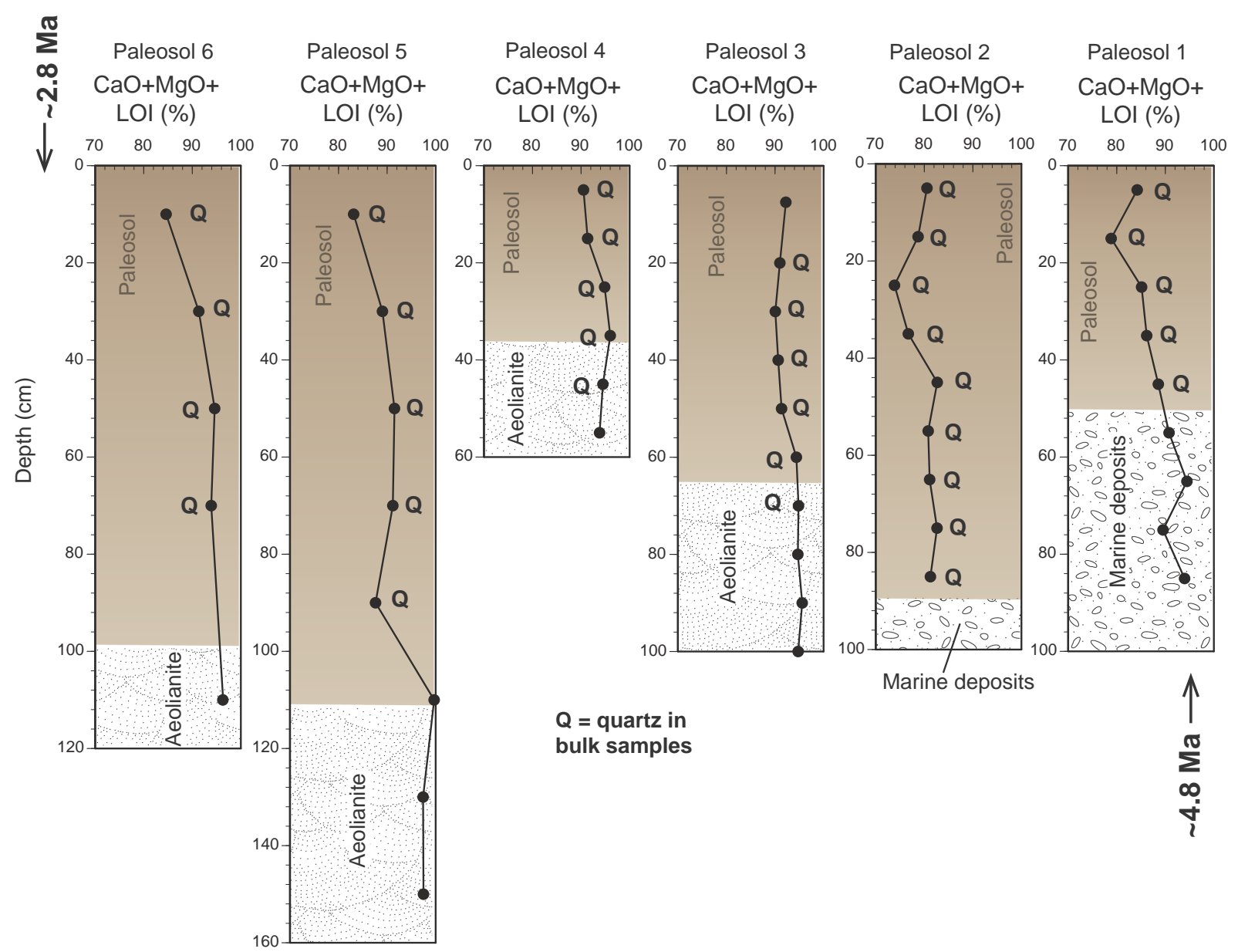

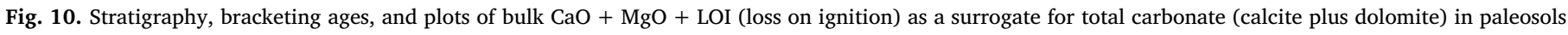

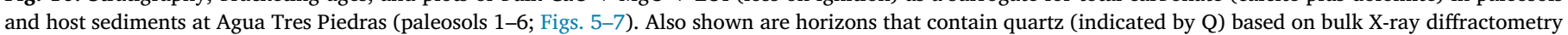
(peaks at $26.6^{\circ}$ and $20.9^{\circ}$, two-theta).

The paleosol of mid-Quaternary age at Punta de Arucas has a bulk mineralogy similar to that at El Mármol. Quartz, plagioclase, and halite are present in all horizons; some horizons contain mica or gypsum. Where quartz is present, values of $\mathrm{SiO}_{2} / \mathrm{TiO}_{2}$ are enriched compared to the underlying basalt (Fig. 13). Within the clay fraction, the paleosol at Punta de Arucas contains smectite, mica, and kaolinite, with the possibility of some amount of clay-sized quartz, as noted for El Mármol and Agua Tres Piedras (Fig. 15). The presence of mica in some of the bulk analyses and all of the clay analyses is mirrored by of $\mathrm{K}_{2} \mathrm{O} / \mathrm{TiO}_{2}$ values that are higher than those in the underlying basalt (Fig. 13).

\subsection{Trace element geochemistry of paleosols at Agua Tres Piedras, Fuerteventura}

For characterization of African dust, we use trace element data from dust trapped on Barbados and Bermuda, islands in the western Atlantic Ocean. Dust samples from these locations were collected by Joseph M. Prospero and his research group at the University of Miami and trace element data for the samples can be found in Muhs et al. (2007, 2010, 2012). All dust analyses were conducted in precisely the same manner as those for the paleosols in the present study and therefore the results are directly comparable. For Miocene volcanic rocks on Fuerteventura, there are, unfortunately, few trace element data available. However, Tornare et al. (2016) provide some trace element data for rocks of this age on Fuerteventura. Such rocks constitute a major part of the island's bedrock that would have existed in pre-Pliocene and Pliocene times (Fig. 2). The other major local unit that could have provided sediments as parent material for the paleosols at Agua Tres Piedras is the suite of rocks found in the Basal Complex (Fig. 2). Rocks of the Basal Complex span a diverse range of lithologies. They include gabbros and basalts, but also dykes and other intrusions, with a wide range in compositions. Trace element data for these rocks are available from several sources, including Ahijado et al. (2001), Allibon et al. (2011), and Holloway and Bussy (2008).

Results indicate that African dust collected on Barbados and Bermuda have similar compositions and both are distinguished from Miocene volcanic rocks and Basal Complex rocks. On a classical Sc-ThLa diagram, African dust collected on both Barbados and Bermuda plot in the upper center (Fig. 16), showing a relative depletion in Sc and enrichment in Th and La, very similar to average upper continental crust (Taylor and McLennan, 1985). Miocene volcanic rocks on Fuerteventura, from the limited data available, show relative depletions in $\mathrm{Th}$, which is typical of mantle-derived rocks, but also show a wide range of concentrations of Sc and La (Fig. 16a). We have previously found relatively high concentrations of La in volcanic rocks on the neighboring island of Lanzarote (Muhs et al., 2010). Nevertheless, the field defined by Sc-Th-La for the Miocene volcanic rocks does not overlap the field defined by African dust. A similar result is seen for rocks and intrusions from the Basal Complex (Fig. 16b). Although some of these rocks have more typical mantle-like compositions, with enriched Sc and depleted La, there is, like the Miocene volcanic rocks, a wide range in Sc and La concentrations. Importantly, all show depletions in Th, and the field of Sc-Th-La defined by Basal Complex rocks and intrusions also does not overlap the field defined by African dust. 


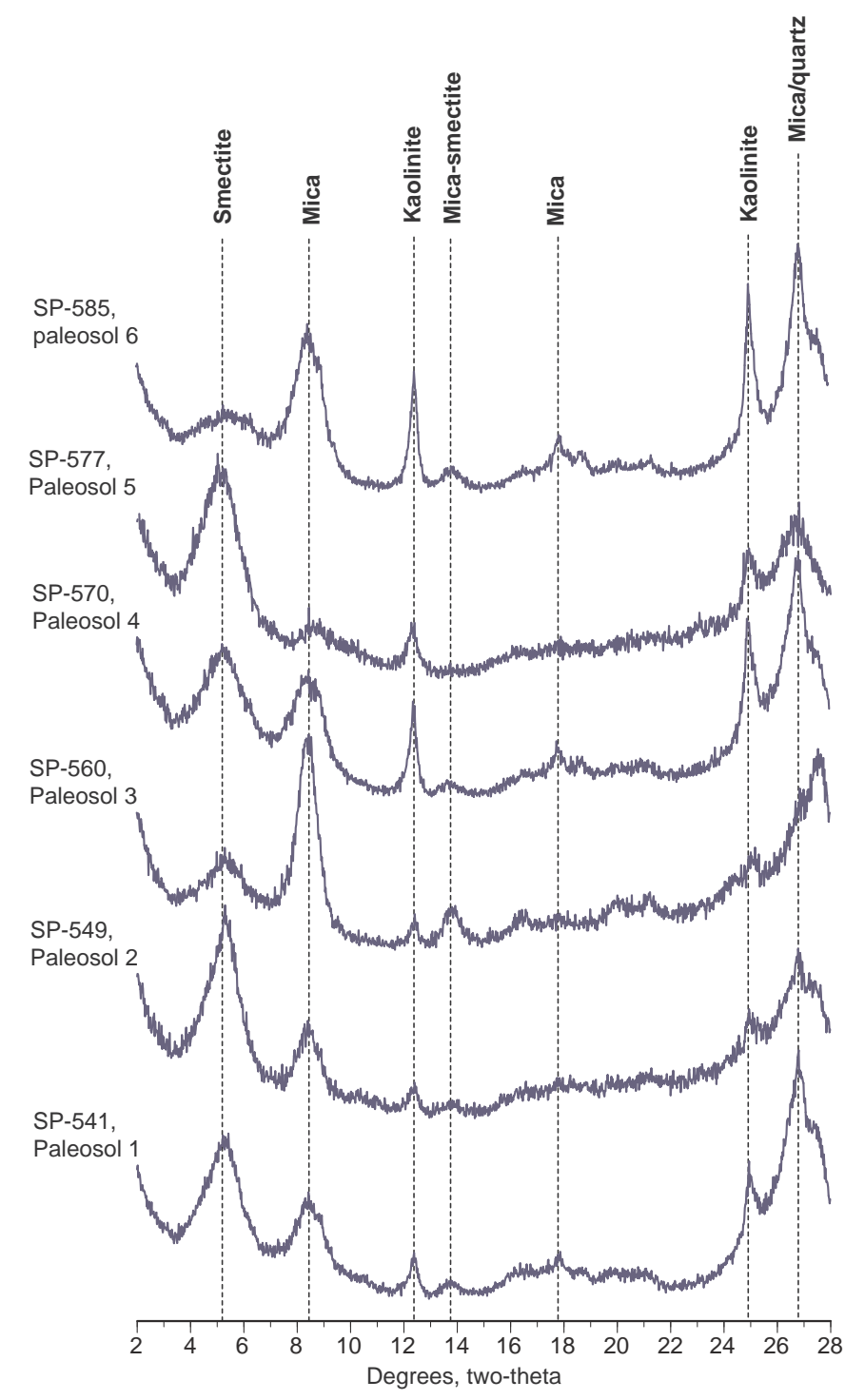

Fig. 11. X-ray diffractograms of glycolated clay $(<2 \mu \mathrm{m})$ fractions of representative horizons of paleosols at Punta Agua Tres Piedras, Fuerteventura, and clay minerals identified.

Paleosols at Agua Tres Piedras also show a fairly broad range of compositions. However, all paleosols have Sc-Th-La compositions that fall between the fields defined by Miocene volcanic rocks and African dust (Fig. 16a). About half the paleosols also fall between the fields defined by Basal Complex rocks and intrusions and African dust (Fig. 16b). The other half of the paleosol samples have Sc-Th-La compositions that overlap a small part of the field defined by Basal Complex rocks.

Because of the wide range in concentrations of La in rocks of Fuerteventura, we can explore the compositional range of these rocks using other immobile trace elements. One of these is Ta, found in a wide range of minerals. Muhs et al. (2010) reported that Pleistocene basalt on the island of Lanzarote can be distinguished from African dust on a Sc-Th-Ta x10 diagram. We determined this composition for rocks from Fuerteventura from published trace element data. Results indicate that, like Lanzarote, Miocene rocks on Fuerteventura have a compositional range for Sc-Th-Ta x10 that has no overlap with African dust (Fig. 16c). Basal Complex rocks also have a fairly wide range of compositions for Sc-Th-Ta x 10, but also show no overlap with African dust (Fig. 16d). Paleosols from Agua Tres Piedras, with one exception, fall between the compositional fields defined by Miocene volcanic rocks and African dust (Fig. 16c). The paleosols also fall between the compositions of Basal Complex rocks and African dust on a Sc-Th-Ta x 10 diagram (Fig. 16d).

Another useful element that can be applied to provenance studies is $\mathrm{Hf}$, which substitutes for $\mathrm{Zr}$ and is therefore found dominantly in zircon. Thus, with mantle-derived rocks that have little or no zircon, Hf concentrations are expected to be low relative to Sc. This result is apparent in a Sc-Hf-Th diagram, where Miocene volcanic rocks of Fuerteventura show high values of Sc and relatively low values of $\mathrm{Hf}$ and Th (Fig. 17a). African dust, with its upper crust-derived origin, plots closer to the center for Sc-Hf-Th. Basal Complex rocks define a compositional field similar to that of the Miocene volcanic rocks, but with a greater degree of variability (Fig. 17b). There is no overlap between Miocene volcanic rocks and African dust for Sc-Hf-Th, and only very slight overlap of Basal Complex rocks with African dust. As is the case with Sc-Th-La, however, paleosols from Agua Tres Piedras fall between the compositional fields of Miocene volcanic rocks and African dust for Sc-Hf-Th (Fig. 17a). Also similar to Sc-Th-La (Fig. 16b), paleosols from Agua Tres Piedras overlap with part of the field for Basal Complex rocks and intrusions, but close to the field for African dust (Fig. 17b).

In an earlier study on Lanzarote, the REE were also found to be effective in discriminating local basalt from African dust (Muhs et al., 2010). Specifically, plots of $\mathrm{La}_{N} / \mathrm{Yb}_{\mathrm{N}}$ vs. Eu/Eu* and $\mathrm{Gd}_{\mathrm{N}} / \mathrm{Yb}_{\mathrm{N}}$ vs. Eu/ $\mathrm{Eu}^{*}$ define geochemical fields for Pleistocene basalt and African dust that show no overlap. As mentioned earlier, however, there are few trace element data for the Miocene volcanic rocks that characterize much of Fuerteventura (Fig. 2). Tornare et al. (2016) provide the only data with the complete suite of REE for these rocks of which we are aware. Their samples all came from the Miocene rocks of the central shield volcano complex (Fig. 2). However, an earlier study by Ancochea et al. (1993) reported REE data for a fewer number of elements (La, Ce, $\mathrm{Yb}$ ), but for a much more comprehensive sampling of the Miocene (Series I of Fuster et al., 1968a) rocks on Fuerteventura, from all three shield volcano complexes (Fig. 2). It seems appropriate, therefore, to determine how representative the more limited number of samples of Tornare et al. (2016) are to the larger data set of Ancochea et al. (1993). Concentrations of the two lightest REE, La and Ce, plot linearly and the data sets from Ancochea et al. (1993) and Tornare et al. (2016) show excellent agreement (Fig. 18a). Plots of La vs. La/Yb also show excellent agreement for rocks of the central shield complex and moderately good agreement for the northern shield complex (Figs. 18b,c). The La/Yb values for the southern shield complex reported by Ancochea et al. (1993) are, however, somewhat higher than those for the central shield complex reported by these workers and Tornare et al. (2016) (Fig. 18d). Thus, in examining the plots of $\mathrm{La}_{\mathrm{N}} / \mathrm{Yb}_{\mathrm{N}} \mathrm{vs}$. $\mathrm{Eu} / \mathrm{Eu}^{*}$ that follow, the reader is cautioned that volcanic rocks of the southern shield complex likely include some phases with higher $\mathrm{La}_{\mathrm{N}} / \mathrm{Yb}_{\mathrm{N}}$ values.

With this qualification in mind, we present plots of $\mathrm{La}_{N} / \mathrm{Yb}_{\mathrm{N}}$ vs. Eu/ $\mathrm{Eu}^{*}$ and $\mathrm{Gd}_{\mathrm{N}} / \mathrm{Yb}_{\mathrm{N}}$ vs. $\mathrm{Eu} / \mathrm{Eu}^{*}$ for Miocene volcanic rocks, Basal Complex rocks, African dust, and paleosols at Agua Tres Piedras. Results show that, as with the other trace elements, African dust collected on Barbados has a REE composition that overlaps that of African dust collected on Bermuda (Fig. 19a). Miocene volcanic rocks from the central shield complex reported by Tornare et al. (2016) have $\mathrm{La}_{N} / \mathrm{Yb}_{\mathrm{N}}$ values that overlap those of African dust, but also include values that are higher. Notably, however, the Miocene volcanic rocks do not exhibit Eu anomalies, i.e., have $\mathrm{Eu} / \mathrm{Eu}^{*}$ values that center around 1.0 (Fig. 19a). In contrast, all African dust samples have negative Eu anomalies, with values ranging between 0.5 and 0.8 . Similar to the Miocene volcanic rocks, Basal Complex rocks, dykes, and intrusions have $\mathrm{La}_{\mathrm{N}} / \mathrm{Yb}_{\mathrm{N}}$ values that span a much wider range $(\sim 2$ to $\sim 25)$ than African dust (Fig. 19b). Also similar to the Miocene volcanic rocks, however, most of the Basal Complex rocks do not have negative Eu anomalies. Indeed, many Basal Complex rocks show positive Eu anomalies, with $\mathrm{Eu} / \mathrm{Eu}^{*}$ values as high as 1.3. Thus, overall, the $\mathrm{La}_{\mathrm{N}} /$ $\mathrm{Yb}_{\mathrm{N}}$ vs. Eu/Eu* plots define geochemical fields that are distinctive for 


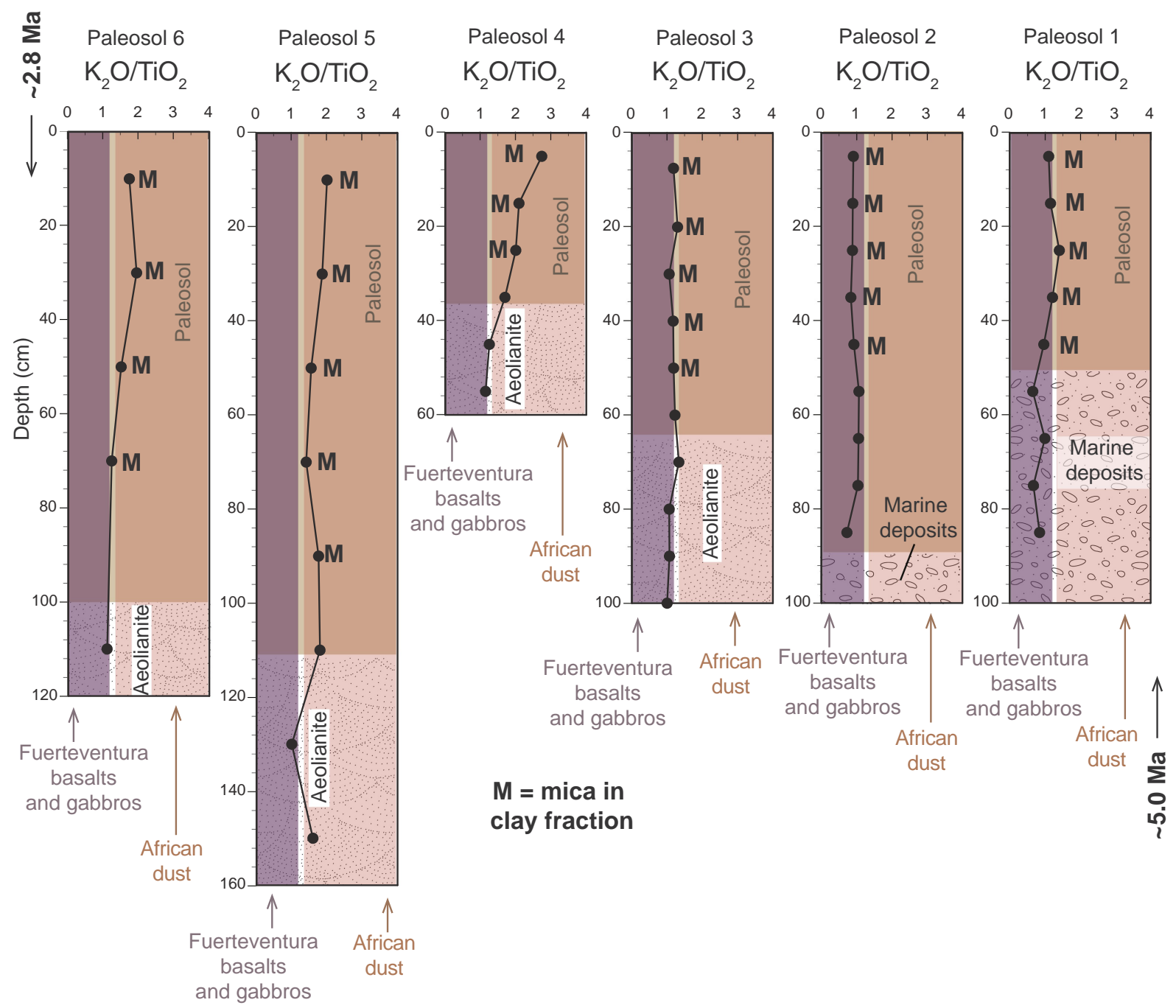

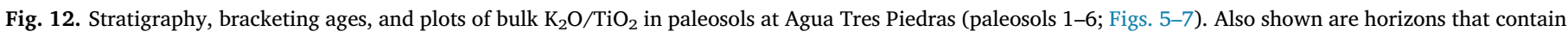

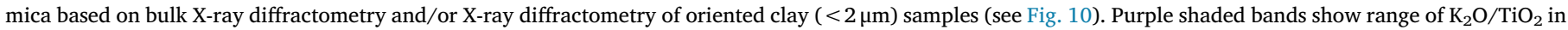

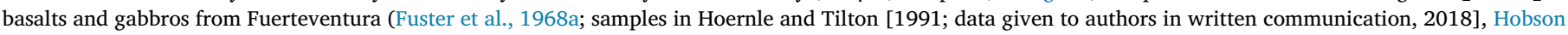

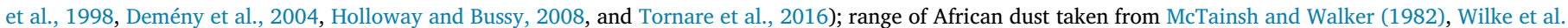

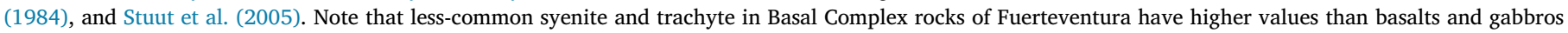

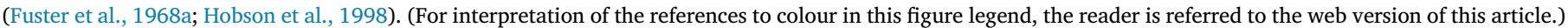

African dust compared to either Miocene volcanic rocks or Basal Complex rocks. Paleosols from Agua Tres Piedras plot between the fields for African dust and both Miocene volcanic rocks and Basal Complex rocks. All paleosols have negative Eu anomalies, with $\mathrm{Eu} / \mathrm{Eu}^{*}$ values ranging from $\sim 0.7$ to $\sim 0.9$ (Fig. 19a,b).

Plots of $\mathrm{Gd}_{\mathrm{N}} / \mathrm{Yb}_{\mathrm{N}}$ vs. Eu/Eu* for rocks from Fuerteventura show an even greater compositional distinction from African dust. Values of $\mathrm{Gd}_{\mathrm{N}} / \mathrm{Yb}_{\mathrm{N}}$ for Miocene volcanic rocks have little overlap with African dust, the latter having much lower values (Fig. 19c). The same is true for Basal Complex rocks, which have little overlap in $\mathrm{Gd}_{N} / \mathrm{Yb}_{\mathrm{N}}$ values for African dust (Fig. 19d). Paleosols from Agua Tres Piedras plot between the geochemical fields for African dust and both Miocene volcanic rocks and Basal Complex rocks (Figs. 19c, d).

\subsection{Trace element geochemistry of paleosols on Gran Canaria}

For Gran Canaria, we compare the trace element composition of paleosols developed on Pliocene and Pleistocene basalt to African dust and the underlying basalts. Aulinas et al. (2010) reported major and trace element data for a number of Pliocene and Quaternary basalts on Gran Canaria. Their samples, like ours, come from the northeastern half of the island, which is dominated by mafic rocks (Fig. 3).

As with the study on Fuerteventura, we first generated a classical ScTh-La diagram to investigate the origin of the paleosols on Gran Canaria. Basalts at El Mármol and those from elsewhere on Gran Canaria define a Sc-Th-La geochemical field (Fig. 20a) overlapping with, but smaller than the Sc-Th-La geochemical field for Miocene volcanic rocks on Fuerteventura (Fig. 16). Both of the Gran Canaria volcanic rock suites define geochemical fields that are distinct from African dust. Nevertheless, paleosols from both Punta de Arucas and El Mármol plot close to both the volcanic rock and African dust fields, but above both, near the La pole (Fig. 20a). This does not allow for easy interpretations, although we suspect that there is variability in the composition of the volcanic rocks on Gran Canaria that perhaps we have not captured. An attempt to overcome this obstacle using a Sc-ThTa $\times 10$ plot, which was successful for our studies of the paleosols on Fuerteventura, unfortunately did not yield much better results (Fig. 20b). Although basalts on Gran Canaria and African dust define geochemical fields that do not overlap, paleosols from both Punta de Arucas, and particularly El Mármol, plot above the fields for both parent materials.

Other geochemical arrays provide better discrimination of parent 

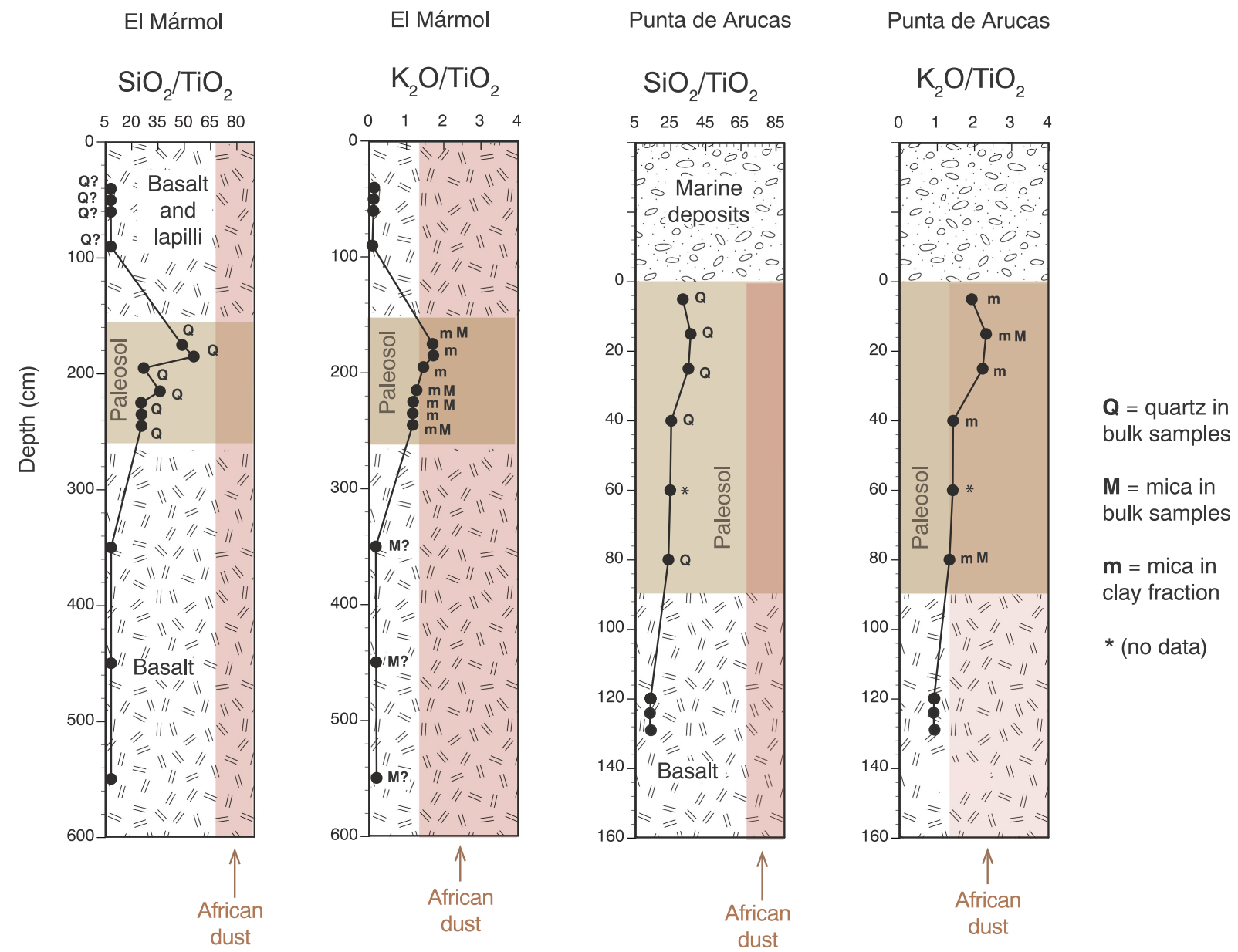

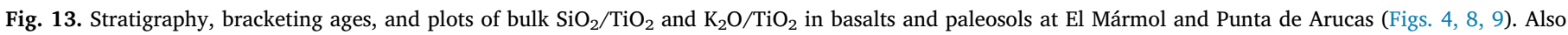

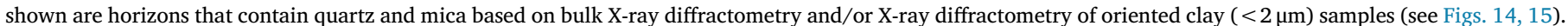

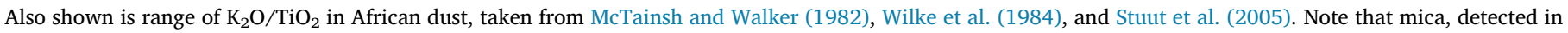
lower basalt at El Mármol, could be due to contamination by modern African dust.

materials and clearer insight on the origin of the paleosols on Gran Canaria. For Sc-Hf-Th, Pliocene basalts that overlie and underlie the paleosol at El Mármol plot in the lower right, typical of mantle-derived rocks enriched in Sc, and show no overlap with African dust (Fig. 21a). Volcanic rocks of Pliocene-Quaternary age from elsewhere on the northeastern half of Gran Canaria (Aulinas et al., 2010) also plot in this region, although they have little overlap with the basalts we sampled. The same general trend is also seen for $\mathrm{Cr} / 10$-Hf-Th, where basalts we sampled and those reported by Aulinas et al. (2010) also plot in the lower right corner, near the $\mathrm{Cr}$ pole (Fig. 21b). As with the Sc-Hf-Th geochemical fields, for Cr/10-Hf-Th, Gran Canaria basalts and African dust show no overlap. At El Mármol, all but one of the horizons of the paleosol plot close to the geochemical field of African dust for Sc-Hf-Th (Fig. 21a). For Cr/10-Hf-Th, all horizons but one plot in or near the field for African dust as well, consistent with the Sc-Hf-Th composition (Fig. 21b).

The distinction in compositions of basalts and African dust that are apparent with Sc-Hf-Th and $\mathrm{Cr} / 10-\mathrm{Hf}-\mathrm{Th}$ are also seen in the REE. A plot of $\mathrm{La}_{\mathrm{N}} / \mathrm{Yb}_{\mathrm{N}}$ vs. Eu/Eu* shows that basalts at $\mathrm{El}$ Mármol and elsewhere on northeastern Gran Canaria (Aulinas et al., 2010) have similar, but distinct compositions, with either no Eu anomaly or very slightly negative Eu anomalies (Fig. 22a). Although there is some overlap in $\mathrm{La}_{\mathrm{N}} / \mathrm{Yb}_{\mathrm{N}}$ values in the basalts at El Mármol and African dust, the basalts studied by Aulinas et al. (2010) show a fairly wide range of $\mathrm{La}_{\mathrm{N}} / \mathrm{Yb}_{\mathrm{N}}$ values and none overlap the field of African dust. On a $\mathrm{Gd}_{N} / \mathrm{Yb}_{\mathrm{N}}$ vs. Eu/ Eu* plot, basalts at El Mármol and elsewhere on Gran Canaria overlap completely, but there is no overlap of either with African dust (Fig. 22b). On the $\mathrm{La}_{\mathrm{N}} / \mathrm{Yb}_{\mathrm{N}}$ vs. Eu/Eu* plot, most horizons of the paleosol at El Mármol fall between the fields defined by basalt and African dust. On the $\mathrm{Gd}_{\mathrm{N}} / \mathrm{Yb}_{\mathrm{N}}$ vs. $\mathrm{Eu} / \mathrm{Eu}^{*}$ plot, all horizons of the paleosol at $\mathrm{El}$ Mármol fall between the basalt and African dust fields, but much closer to the African dust field (Fig. 22b).

Results for the paleosol developed on Pleistocene basalt and overlain by marine deposits at Punta de Arucas are very similar to those for the paleosol at El Mármol. For both Sc-Hf-Th and $\mathrm{Cr} / 10-\mathrm{Hf}-\mathrm{Th}$, all horizons of the paleosol at Punta de Arucas fall within or very close to the field for African dust (Figs. 21c, d). On both $\mathrm{La}_{\mathrm{N}} / \mathrm{Yb}_{\mathrm{N}} \mathrm{vs}$. Eu/Eu* and $\mathrm{Gd}_{\mathrm{N}} / \mathrm{Yb}_{\mathrm{N}}$ vs. Eu/Eu* plots, all horizons of the paleosol plot between African dust and basalt, based on $\mathrm{La}_{\mathrm{N}} / \mathrm{Yb}_{\mathrm{N}} \mathrm{vs}$. $\mathrm{Eu} / \mathrm{Eu}^{*}$, or between the two fields, but closer to African dust, based on $\mathrm{Gd}_{\mathrm{N}} / \mathrm{Yb}_{\mathrm{N}}$ vs. Eu/Eu* (Fig. 22a,b).

\section{Discussion}

\subsection{Mineralogical evidence for the origin of paleosols on the Canary Islands}

The quartz found in almost all horizons of all paleosols at Agua Tres Piedras is interpreted to be exotic to Fuerteventura. Quartz is apparent in bulk XRD analyses, but may also be present in the clay-sized $(<2 \mu \mathrm{m})$ fraction of the paleosols, based on the relatively high XRD peaks at $26.6^{\circ}$ (coincident with mica, but higher than can be explained by mica alone). Quartz is either rare or completely absent in rocks of the Canary 


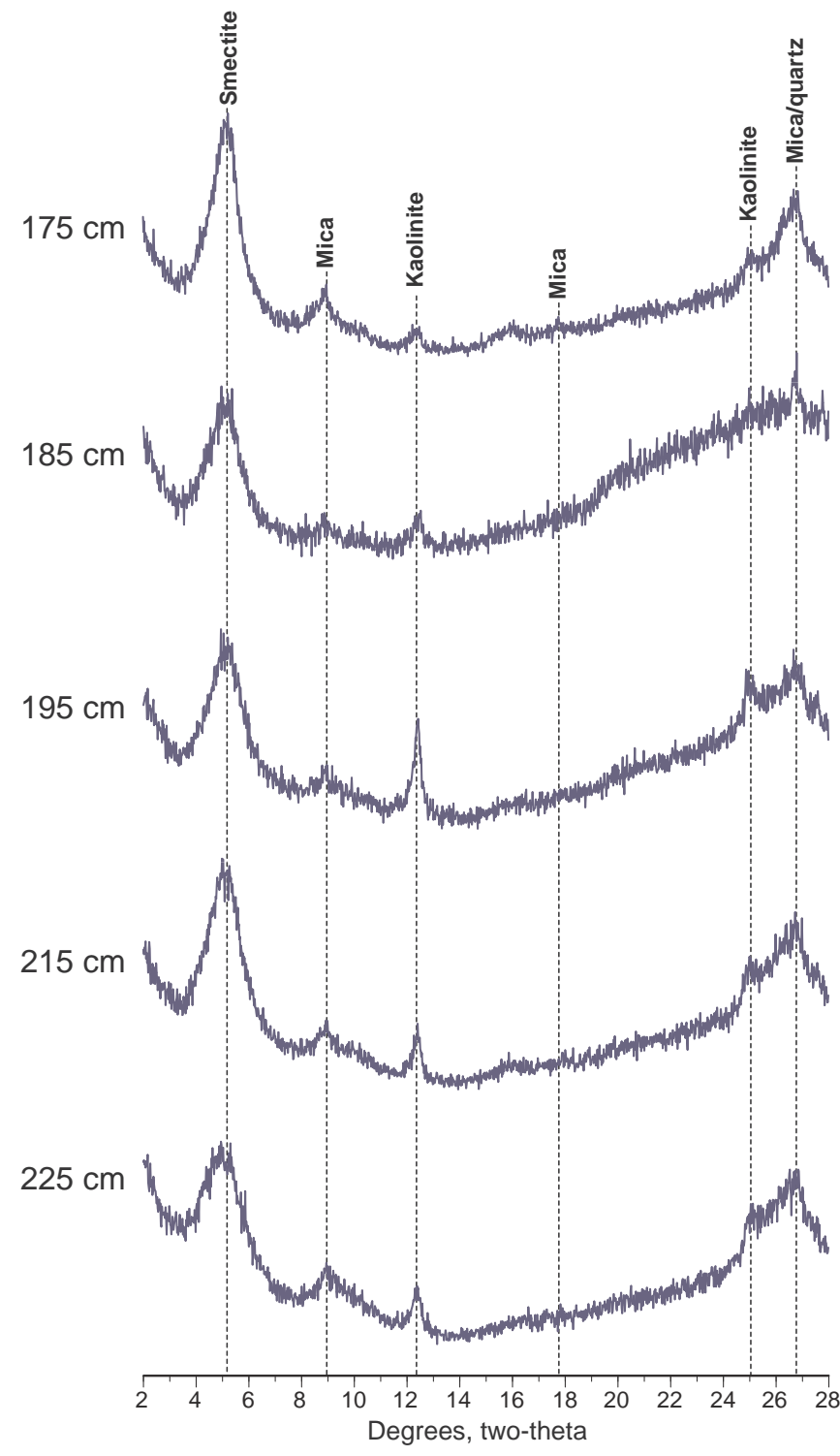

Fig. 14. X-ray diffractograms of glycolated clay $(<2 \mu \mathrm{m})$ fractions of paleosols at El Mármol, Gran Canaria, and clay minerals identified.

Islands (Carracedo and Troll, 2016). On Fuerteventura, none of the basalts or other mafic rocks on the island contain quartz, based on detailed petrographic studies reported by Fuster et al. (1968a). The only local source of quartz on Fuerteventura of which we are aware is the sequence of Mesozoic sediments found in the Basal Complex, which would have existed as part of the island during the Pliocene (see Fuster et al., 1968a and Carracedo and Troll, 2016, p. 536-537). After accumulation on the insular shelf, quartz particles from these sediments could then have been entrained, by waves and wind, along with the more abundant carbonate particles, to supply the storm-derived marine sediments and aeolianites that are now exposed on the coast. This scenario, however, does not explain the absence of quartz in the sediments that host the quartz-bearing paleosols (Fig. 10). We found quartz only at a single depth in the aeolianite hosting paleosol 3 and at a single depth in the aeolianite hosting paleosol 4 at Agua Tres Piedras. Both of these occurrences were in depth zones immediately below the paleosols. If quartz had been locally derived, it should be apparent at most or all depths of the marine sediments and aeolianites.

Quartz in paleosols is also interpreted to be exotic to the island of Gran Canaria. Quartz is not present in the basalt that underlies the Pliocene paleosol at El Mármol, nor is it present in the basalt that

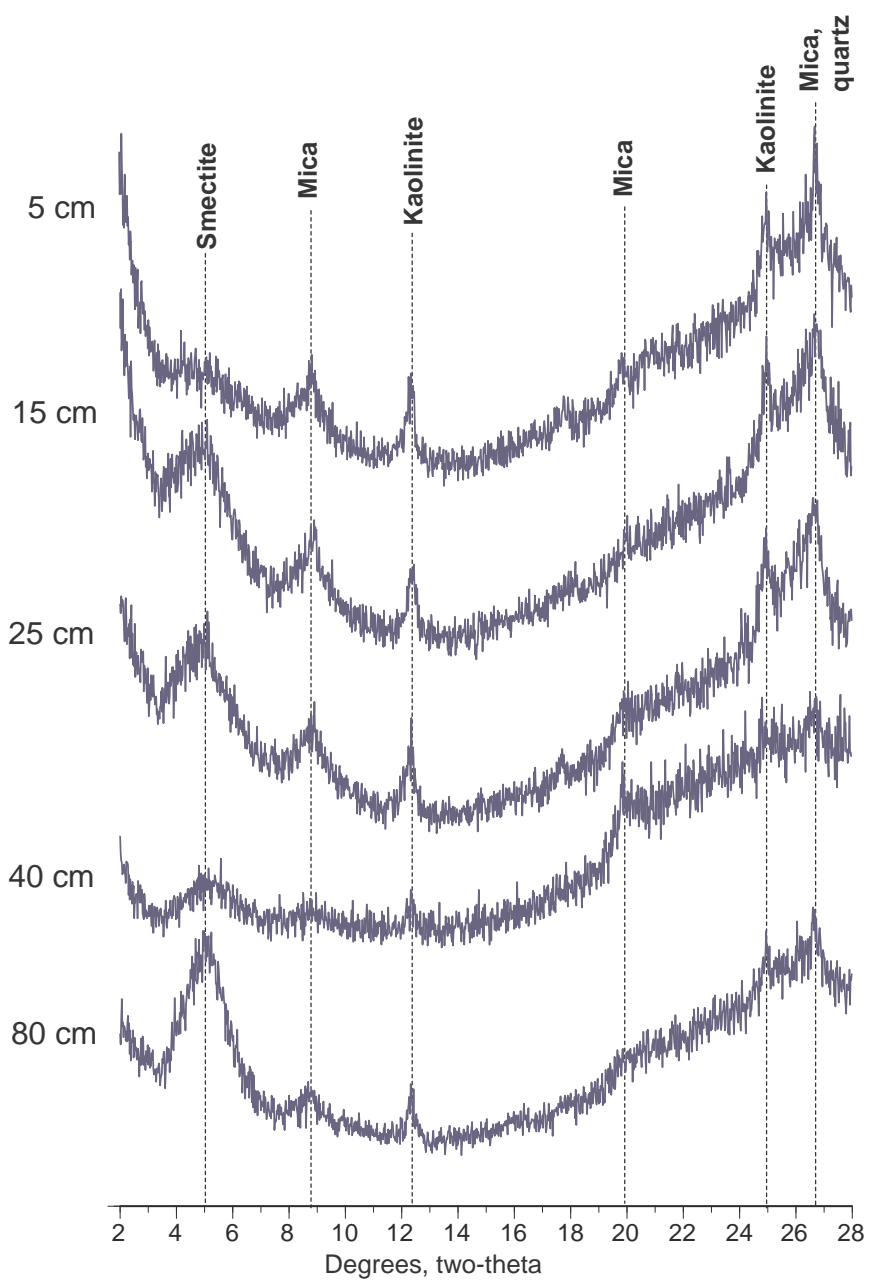

Fig. 15. X-ray diffractograms of glycolated clay $(<2 \mu \mathrm{m})$ fractions of paleosols at Punta de Arucas, Gran Canaria, and clay minerals identified.

underlies the paleosol at Punta de Arucas (Fig. 13). Very small peaks at $26.6^{\circ}$ were observed in bulk XRD samples of the lapilli that overlies the paleosol at El Mármol (Fig. 13), but the peaks are so small that we are not certain they represent quartz. An interpretation of quartz as an exotic component of most paleosol horizons at both localities is supported by substantially higher $\mathrm{SiO}_{2} / \mathrm{TiO}_{2}$ values in the soil horizons compared to the underlying basalts (Fig. 13). It is worth noting that $\mathrm{SiO}_{2} / \mathrm{TiO}_{2}$ values in the lapilli above the paleosol at $\mathrm{El} \mathrm{Mármol} \mathrm{are} \mathrm{si-}$ milar to the quartz-free basalts underlying the paleosol (Fig. 13). On the northeastern side of Gran Canaria (Fig. 4), the dominant rocks are mafic, primarily basalts, and Fuster et al. (1968b), in their petrographic studies of these rocks, did not report the presence of quartz. On the southwestern half of the island, felsic rocks are present (Fig. 4), which are described by Fuster et al. (1968b) as primarily trachytes, syenites, and phonolites. Even in these felsic rocks, Fuster et al. (1968b, p. 202) note that they have not seen primary quartz, although they did report minor secondary quartz in places. In any case, delivery of even rare secondary quartz from the southwestern part of the island to the northeastern part by fluvial or colluvial processes is unlikely, because drainage from the crest of the island is directed to the southwest, away from where the paleosols are situated (Fig. 4).

Mica, found in the clay $(<2 \mu \mathrm{m})$ fraction of the paleosols at Agua Tres Piedras (Figs. 11, 12), is also interpreted to be exotic to the island of Fuerteventura. Within the clay fraction, both smectite and kaolinite observed in the paleosols can, in principle, be explained by chemical weathering (hydrolysis) of plagioclase from the local basalt. However, it does not seem likely that much chemical weathering has occurred in 

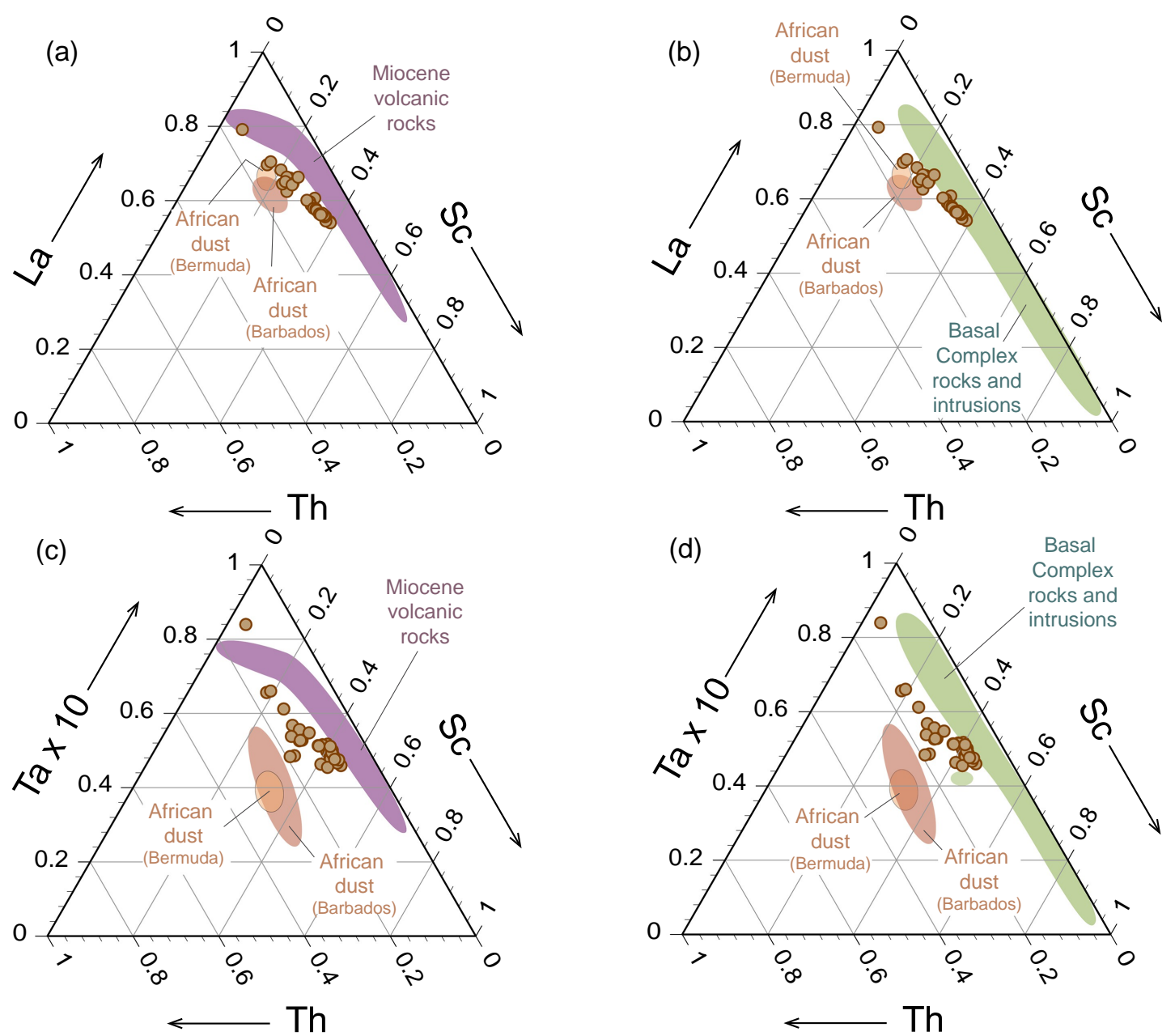

Fig. 16. (a) and (b): plots of Sc-Th-La for paleosols at Agua Tres Piedras (filled brown circles) compared to: African dust collected on Barbados (data from Muhs et al., 2007, 2010) and Bermuda (Muhs et al., 2012); Miocene volcanic rocks on Fuerteventura (data from Tornare et al., 2016); Basal Complex rocks, dykes, and other intrusions (data from Ahijado et al., 2001 and Holloway and Bussy, 2008, and Allibon et al., 2011). (c) and (d): plots of Sc-Th-Ta x 10 for paleosols at Agua Tres Piedras (filled brown circles) compared to: African dust collected on Barbados (data from Muhs et al., 2007, 2010) and Bermuda (Muhs et al., 2012); Miocene volcanic rocks on Fuerteventura (data from Tornare et al., 2016); and Basal Complex rocks, dykes, and other intrusions (data from Ahijado et al., 2001 and Holloway and Bussy, 2008, and Allibon et al., 2011). (For interpretation of the references to colour in this figure legend, the reader is referred to the web version of this article.)

these paleosols. Calcite is abundant in all horizons of all paleosols (Fig. 10) and it seems likely that when these host sediments were first exposed subaerially, calcite would have to have been leached before any alteration of plagioclase by hydrolysis to clay minerals (smectite, kaolinite, and mica) would have taken place. It is particularly difficult to explain the origin of clay-sized mica in these paleosols from pedogenesis and chemical weathering. True cases of pedogenic mica, even in situations where chemical weathering is documented, are actually extremely rare (Fanning and Keramidas, 1977). Therefore, we do not attribute the presence of clay-sized mica to chemical weathering of basalt-derived minerals. We cannot rule out a local detrital origin for mica, however, because Fuster et al. (1968a) reported biotite as an accessory mineral in pyroxenites, syenites, and Series I basalts of Fuerteventura. Most horizons of the paleosols, however, have $\mathrm{K}_{2} \mathrm{O} / \mathrm{TiO}_{2}$ values that are higher than basalts and gabbros of Fuerteventura, coincident with the zones that show mica in the clay fractions of the paleosols (Fig. 12). Furthermore, the soil horizons with higher $\mathrm{K}_{2} \mathrm{O}$ / $\mathrm{TiO}_{2}$ values fall into the range of what has been reported for African dust. However, the less-common felsic rocks of Fuerteventura also have relatively high $\mathrm{K}_{2} \mathrm{O} / \mathrm{TiO}_{2}$ values, likely due to the presence of $\mathrm{K}$-feldspar (see Fuster et al., 1968a, Table 5). Thus, we cannot completely rule out these rocks as a potential source of the elevated $\mathrm{K}_{2} \mathrm{O} / \mathrm{TiO}_{2}$ values in the paleosols.
Clay-sized mica is also present in the paleosols on Gran Canaria, at both El Mármol and Punta de Arucas (Figs. 14, 15). Although Fuster et al. (1968b, p. 231) reported some "secondary biotite" in vesicles of some of the mafic Series II rocks of Gran Canaria, this mineral does not appear to be a major component of the rocks on the northeastern part of the island. We observed some minor mica in the bulk XRD analyses of the underlying basalt at El Mármol, but, as discussed earlier, we cannot exclude the possibility that this mica is itself African dust that is simply contaminating the basalt samples. Within the paleosols at both El Mármol and Punta de Arucas, $\mathrm{K}_{2} \mathrm{O} / \mathrm{TiO}_{2}$ values are elevated compared to the overlying and underlying basalts, consistent with the presence of mica in these zones (Fig. 13).

In addition to the origin of quartz and mica, it is interesting to consider the origin of dolomite found in the paleosols at Agua Tres Piedras. In an early study of African dust transport across the Atlantic Ocean, Delany et al. (1967) noted the presence of dolomite in dust samples they collected on the island of Barbados. Further, they showed that core-top samples from Atlantic Ocean sediments showed a systematic decrease in dolomite content from near the northwestern African coast across the Atlantic to near Barbados. Silt-sized sediments they collected in Algeria and Egypt all contained dolomite, thus suggesting the possibility that dolomite could be derived from Saharan rocks and transported by wind across the Atlantic. 
(a)

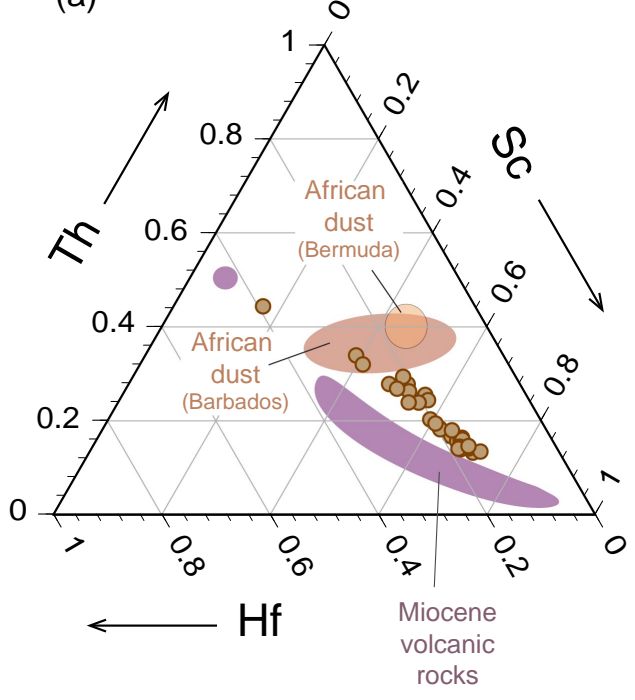

(b)

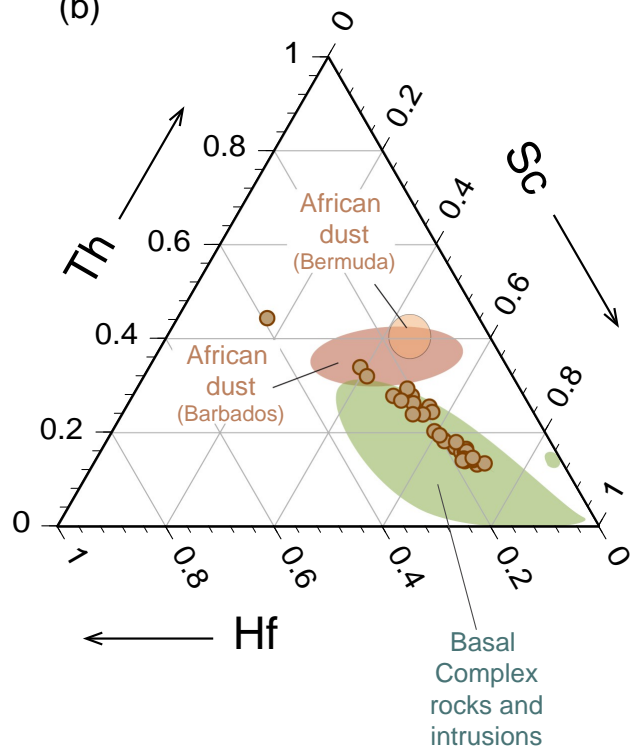

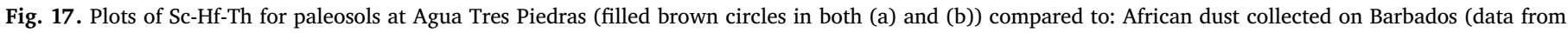

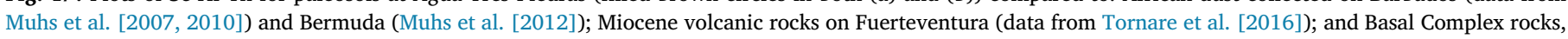

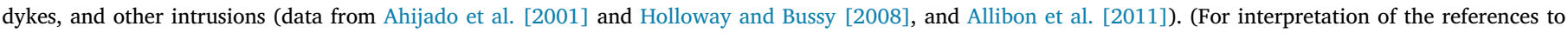
colour in this figure legend, the reader is referred to the web version of this article.)

Although the geographic trends of dolomite across the Atlantic Ocean presented by Delany et al. (1967), combined with the abundance of this mineral in the paleosols at Agua Tres Piedras, are compelling observations for an aeolian origin, another explanation seems more likely. Land (1973) showed that in a coastal setting of Jamaica very similar to that of Agua Tres Piedras, Pleistocene limestone has undergone diagenetic alteration of calcite and aragonite to dolomite by a mix of seawater (with high $\mathrm{Mg}$ content) and fresh water. The geomorphic and hydrologic setting at Agua Tres Piedras is similar to that described by Land (1973) for Jamaica, and there is a very high calcite content in the marine sediments and aeolianite at this locality, also similar to Jamaica. Although detailed thin section analyses would be useful in assessing this hypothesis, diagenetic alteration of calcite seems to be a likely explanation for the origin of dolomite at Agua Tres Piedras. Furthermore, if the dolomite were of detrital (aeolian) origin, it should be present in similar abundances in the paleosol at El Mármol. At El Mármol, carbonate-rich marine sediment is not present, and therefore the diagenetic model of Land (1973) would not apply. There are only modest amounts of dolomite in a single horizon of the paleosol at El Mármol, and none in the paleosol at Punta de Arucas. We conclude from these observations that it is more likely that the dolomite at Agua Tres Piedras is due to diagenetic alteration of the calcite-rich marine sediments and aeolianite.

\subsection{Trace element geochemical evidence for the origin of paleosols on the Canary Islands}

Trace element geochemistry provides some of the most definitive evidence for a partial aeolian origin for the paleosols of the Canary Islands. On Fuerteventura, both Miocene volcanic rocks and rocks of the older Basal Complex have Sc-Th-La compositions that are similar to each other, but both are distinct from African dust collected on Barbados and Bermuda (Fig. 16). Paleosols at Agua Tres Piedras have Sc-Th-La compositions that fall between the fields defined by either of the local rocks and African dust. It is clear from these plots that African dust does not explain all of the composition of the paleosols, but importantly, the local rocks do not either. No combination of Miocene volcanic rocks and Basal Complex rocks can account for the composition of the paleosols based on relative abundances of Sc, Th, and La. The simplest explanation for the composition of the paleosols at Agua Tres Piedras is that they contain a mix of locally derived minerals (primarily plagioclase and heavy minerals) and long-range-transported dust from Africa (quartz, mica, smectite, and kaolinite).

Two trace element trios support the interpretations made from ScTh-La plots. Use of Ta in place of La in a ternary plot yields geochemical fields for Miocene volcanic rocks and Basal Complex rocks that are very similar to Sc-Th-La (Fig. 16). On a Sc-Th-Ta x 10 plot, African dust shows a somewhat greater range of values compared to that for Sc-Th$\mathrm{La}$, but the field so defined is again distinct from either of the local bedrock groups. Fuerteventura paleosols have compositions that plot between African dust and either Miocene volcanic rocks or Basal Complex rocks, again suggesting that minerals in the buried soils are in part derived from local sources and in part from long-range-transported sources. The same interpretations can be made from Sc-Hf-Th plots (Fig. 17), where Hf is a trace element that follows Zr. Thus, this plot incorporates the relative abundance of zircons, not present in local basalts. A plot of Sc-Hf-Th also suggests that the soils are a mix of local and exotic sources (Fig. 17a). One difference that emerges from Sc-HfTh plots, however, is that it would be permitted (but not required) that some (but not all) of the paleosol horizons could be dominated by minerals derived from Basal Complex rocks (Fig. 17b).

The REE are sensitive indicators of rock origins. On Fuerteventura, Miocene volcanic rocks have $\mathrm{La}_{\mathrm{N}} / \mathrm{Yb}_{\mathrm{N}}$ values that overlap those of Basal Complex rocks, as well as African dust (Fig. 19a, b). However, Eu/Eu* values in Basal Complex rocks, while overlapping the range of such values in Miocene volcanic rocks, are generally higher, and both rock units have $\mathrm{Eu} / \mathrm{Eu}^{*}$ values that do not overlap the range of values in African dust. On a $\mathrm{La}_{N} / \mathrm{Yb}_{\mathrm{N}}$ vs. Eu/Eu* plot, paleosols at Agua Tres Piedras fall between the fields defined by African dust and either local bedrock type on Fuerteventura (Figs. 19a, b). Plots of $\mathrm{Gd}_{\mathrm{N}} / \mathrm{Yb}_{\mathrm{N}}$ vs. Eu/ $\mathrm{Eu}^{*}$ provide even greater discriminating power. Although the ranges of $\mathrm{Gd}_{\mathrm{N}} / \mathrm{Yb}_{\mathrm{N}}$ values in Miocene volcanic rocks and Basal Complex rocks are similar, both are greater than the range of values for African dust. Thus, both local rock types on Fuerteventura define geochemical fields that are completely distinct from African dust (Fig. 19c, d). Paleosols at Agua Tres Piedras fall between the fields for African dust and either rock type, indicating that they have formed in part from a local source or sources and in part from long-range-transported dust. In summary, 
(a) All Series I volcanic rocks

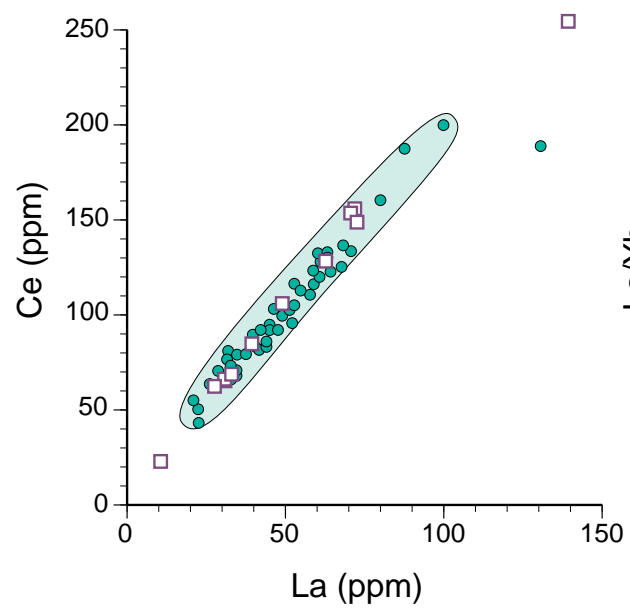

(c) Central Shield Complex (b) Northern Shield Complex

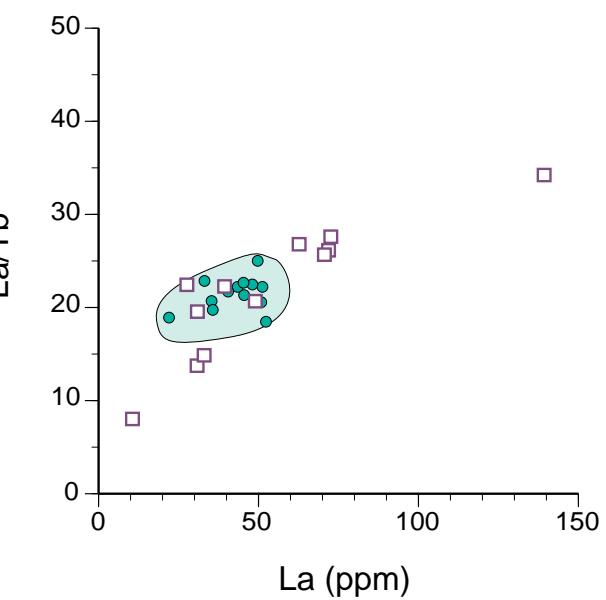

Fig. 18. Comparison of rare earth element data for Miocene (Series I) volcanic rocks of Fuerteventura from two different studies: (a) La vs. Ce for all rocks; (b) La vs. La/Yb for Northern Shield Complex rocks; (c) La vs. $\mathrm{La} / \mathrm{Yb}$ for Central Shield Complex rocks; (d) La vs. La/Yb for Southern Shield Complex rocks. Filled green circles (and green shades) are data from Ancochea et al. (1993) for each shield (in (b), (c), and (d)). Open blue squares are all data from Tornare et al. (2016), and are all from the Central Shield Complex. Note that $\mathrm{La} / \mathrm{Yb}$ values in these plots are not chondrite-normalized. (For interpretation of the references to colour in this figure legend, the reader is referred to the web version of this article.)

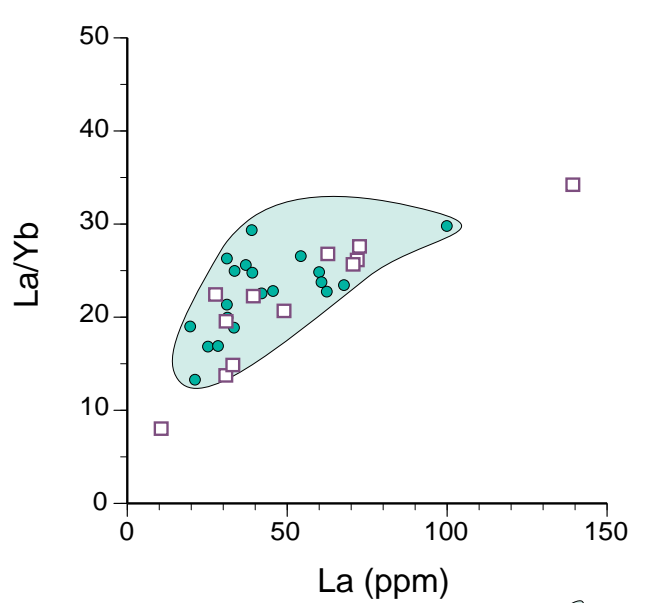

Ancochea et al. (1993)

口 Tornare et al. (1993) (d) Southern Shield Complex

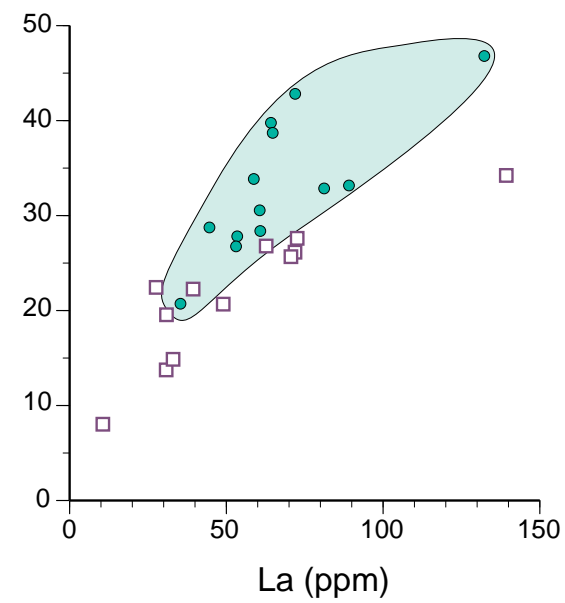

the Sc-Th-La, Sc-Th-Ta x 10, Sc-Hf-Th, $\mathrm{La}_{\mathrm{N}} / \mathrm{Yb}_{\mathrm{N}}$ vs. Eu/Eu*, and $\mathrm{Gd}_{\mathrm{N}} /$ $\mathrm{Yb}_{\mathrm{N}}$ vs. Eu/Eu* plots all converge on a similar conclusion, namely, that the paleosols on Fuerteventura cannot be explained solely by derivation from local sources. The compositions of the paleosols require a component of African dust.

Results from Gran Canaria are consistent with those from Fuerteventura. The Sc-Th-La and Sc-Th-Ta x 10 plots do not yield certain conclusions about the origin of the paleosols at El Mármol and Punta de Arucas (Fig. 20). However, Sc-Hf-Th and Cr/10-Hf-Th plots define clear differences in composition between volcanic rocks of northeastern Gran Canaria and African dust (Fig. 21). With the exception of one horizon at El Mármol, paleosols at that locality and Punta de Arucas fall on or near the field defined by African dust on both Sc-Hf-Th and $\mathrm{Cr} / 10$-Hf-Th plots (Fig. 21). These observations indicate that on the basis of these elements, the soils are likely derived dominantly from African dust. Plots of $\mathrm{La}_{\mathrm{N}} / \mathrm{Yb}_{\mathrm{N}}$ vs. Eu/Eu* and $\mathrm{Gd}_{\mathrm{N}} / \mathrm{Yb}_{\mathrm{N}}$ vs. Eu/Eu* both define distinct geochemical fields for volcanic rocks of northeastern Gran Canaria and African dust (Fig. 22). Paleosols from El Mármol and Punta de Arucas fall either between the fields defined by the local volcanic rocks and African dust $\left(\mathrm{La}_{\mathrm{N}} / \mathrm{Yb}_{\mathrm{N}} \mathrm{vs}\right.$. $\left.\mathrm{Eu} / \mathrm{Eu}^{*}\right)$ or very close to the African dust field $\left(\mathrm{Gd}_{\mathrm{N}} / \mathrm{Yb}_{\mathrm{N}}\right.$ vs. Eu/Eu*). These data are consistent with Sc-Hf-Th and $\mathrm{Cr} / 10$-Hf-Th plots indicating a dominantly African dust source for the paleosols on Gran Canaria.

\subsection{Paleoclimatic implications of African dust inputs to paleosols of Pliocene-Pleistocene age on the Canary Islands}

If our interpretations of African dust inputs to paleosols on Fuerteventura and Gran Canaria are correct, they have important implications for paleoclimate. Both the mineralogical and geochemical results presented here do not specifically require Africa as a dust source for the paleosols, merely that a sediment of average upper crustal composition must be a source. Nevertheless, given its proximity to the Canary Islands, Africa is the simplest choice for the source of such sediments. This interpretation is supported by the abundant evidence for African dust inputs to Canarian soils and paleosols during the Holocene and Pleistocene (Muhs et al., 2010; Huerta et al., 2015; Menéndez et al., 2019; Roettig et al., 2019).

Studies of satellite imagery show that on a global basis, modern dust sources are clearly linked to regions with specific characteristics (Prospero et al., 2002). These conditions, in addition to wind strength, aridity, and a lack of protective vegetation, also include regions characterized by large structural and topographic basins, where fine-grained sediments can be delivered from nearby mountain ranges and accumulate as supplies for aeolian entrainment. Many continents host such regions, including interior Australia, Central Asia, the Arabian Peninsula, and parts of the Americas, but North Africa is by far the largest 
(a)

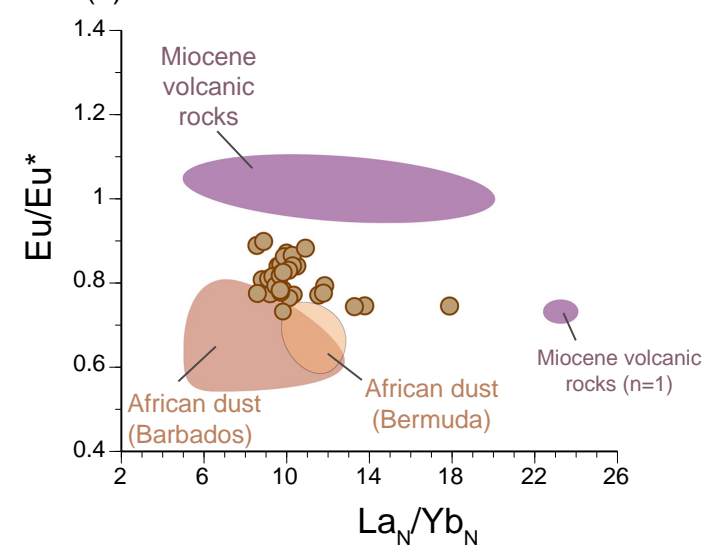

(c)

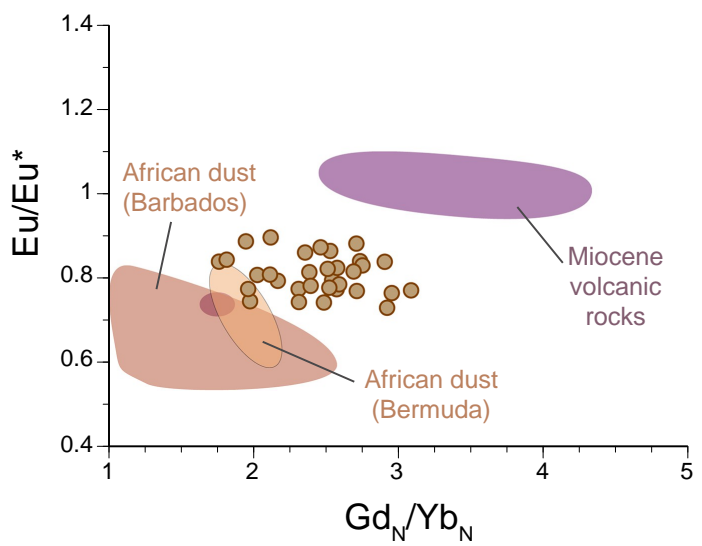

(b)

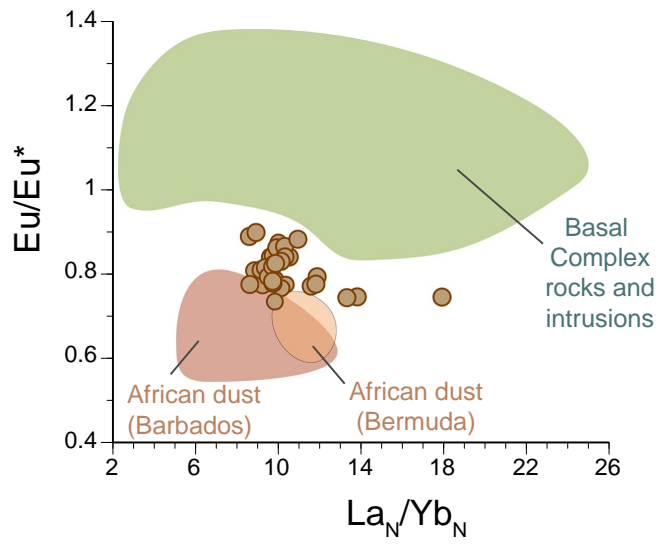

(d)

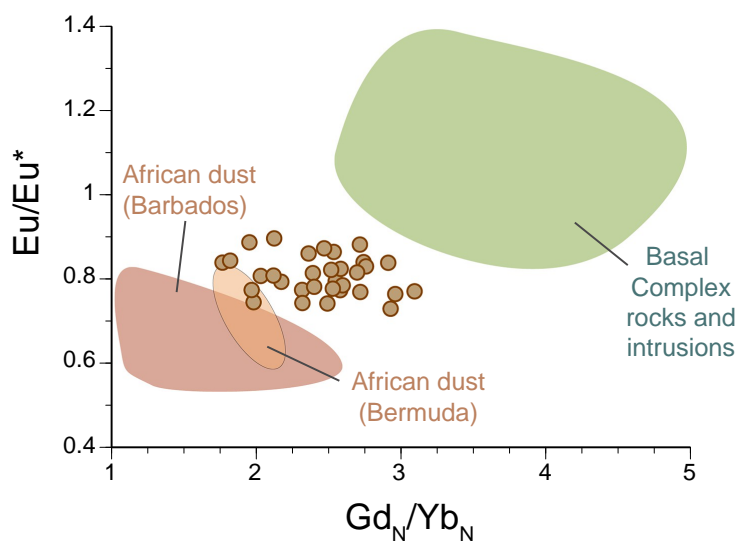

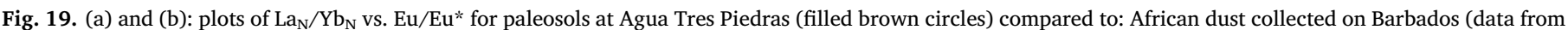

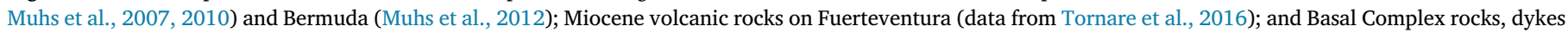

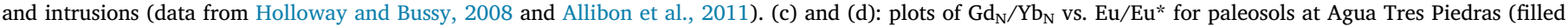

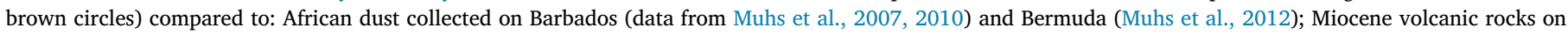

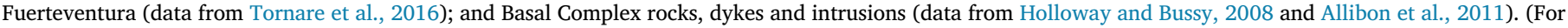
interpretation of the references to colour in this figure legend, the reader is referred to the web version of this article.)

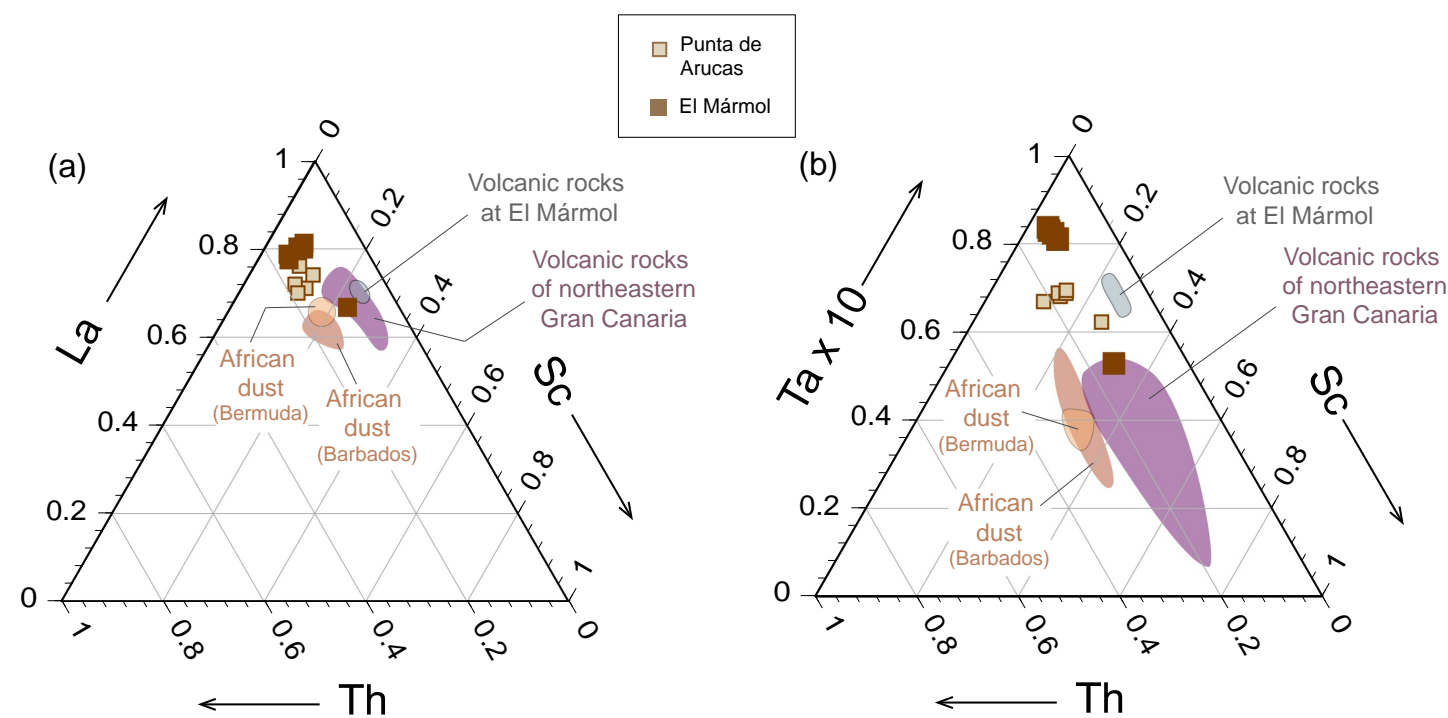

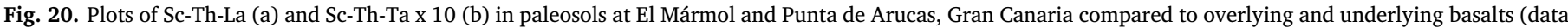

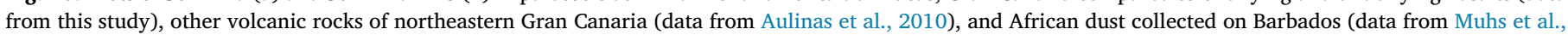
2007, 2010) and Bermuda (Muhs et al. [2012]). 

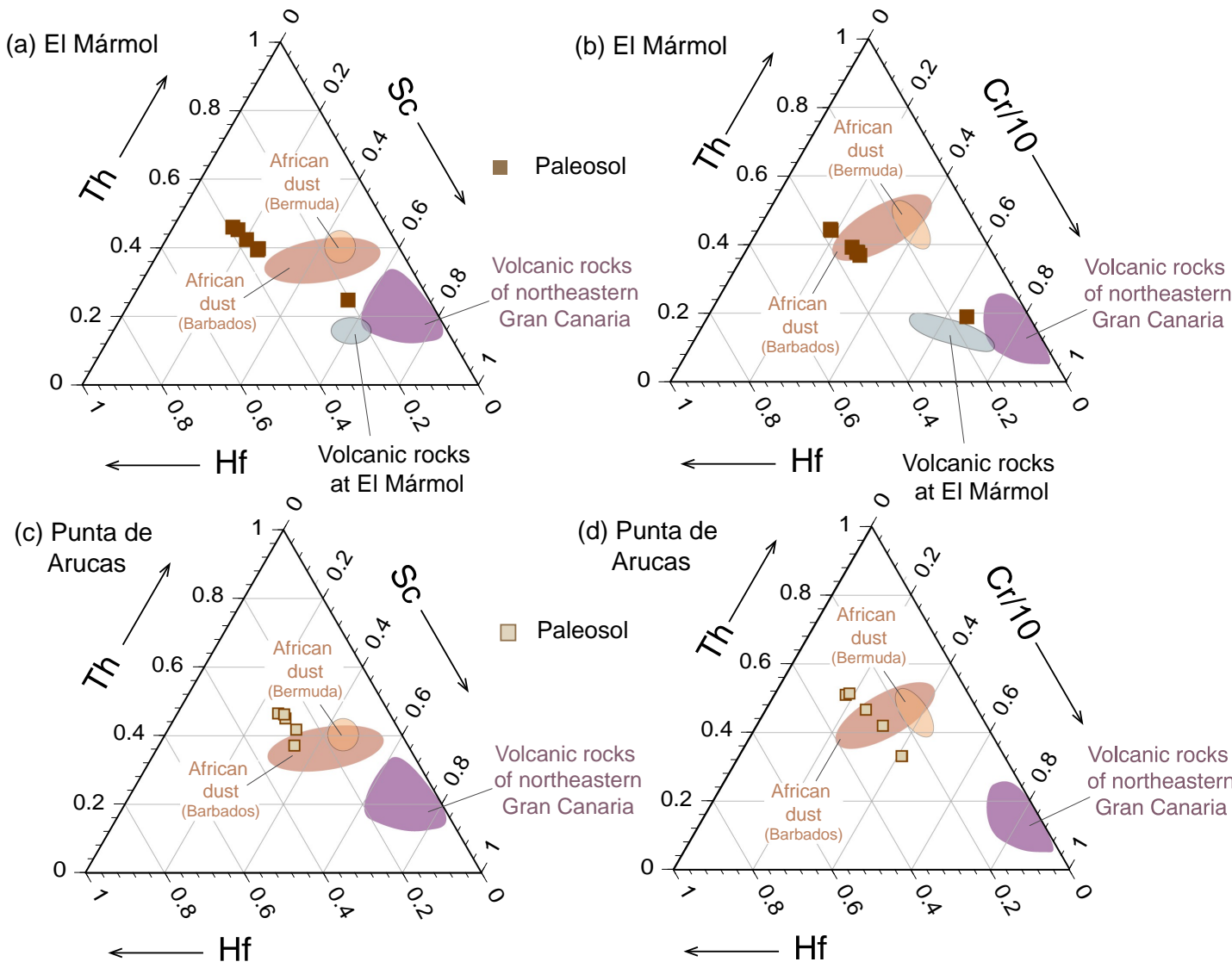

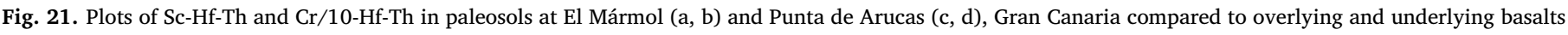

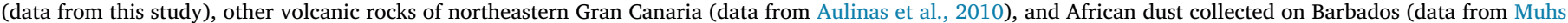
et al. [2007, 2010]) and Bermuda (Muhs et al. [2012]).

such source. Indeed, modeling of dust flux during both modern (interglacial) and last-glacial time periods indicates that North Africa is the largest source of dust during both warm and cold periods of the Quaternary (Mahowald et al., 2006), consistent with modern satellite observations (Prospero et al., 2002).

Based on stratigraphy, paleontology, and numerical ages reviewed earlier, the paleosols at Agua Tres Piedras are thought to have formed between $\sim 4.8 \mathrm{Ma}$ and $\sim 2.8 \mathrm{Ma}$, during the Pliocene (Meco et al., 2006, 2007, 2011, 2015, 2016; Betancort et al., 2016; Carracedo and Troll, 2016). The volcanic flows (and by inclusion, the intercalated paleosol) at El Mármol on Gran Canaria are dated to between 3.0 Ma and 2.9 Ma (Guillou et al., 2004b) and the section at Punta de Arucas is dated to $\sim 0.4 \mathrm{Ma}$ (Meco et al., 2002). Menéndez et al. (2019) recently studied a paleosol that formed between $\sim 2.3 \mathrm{Ma}$ and $\sim 1.46$ Ma near Ingenio on Gran Canaria (Fig. 3) and also documented an African dust component. Thus, based on this latter study and the present one, the paleosols on Fuerteventura and Gran Canaria span the early Pliocene, late Pliocene, early Pleistocene, and middle Pleistocene. Mineralogical and geochemical evidence indicate that all paleosols contain at least a component of African dust. It follows from these observations that some part or parts of Africa have been arid enough to generate dust since at least the early Pliocene and those conditions extended, not necessarily continuously, into the late Pliocene and Pleistocene.

The results reported here can be compared with a more continuous record of African aridity by an examination of the estimated dust flux to ODP Site 659, between the Canary Islands and the Cape Verde Islands (Fig. 1). As mentioned earlier, according to Tiedemann et al. (1989), siliciclastic sediment offshore Africa at this and nearby sites comes from three sources: (1) aeolian, as dust from Africa; (2) fluvial, also from Africa, but limited to sites close to the coast; and (3) turbidites, limited to local sources. Tiedemann et al. (1989) consider aeolian input to be the most important of these sediment transport processes at all sites they studied, including ODP Site 659. Based on oxygen isotope stratigraphy and paleomagnetic data, the sediment record at ODP Site 659 likely extends back to $\sim 8.0 \mathrm{Ma}$. Using the presence of quartz and considering particle size data, Tiedemann et al. (1989) have estimated the flux of dust to ODP Site 659 over the length of the record in their core (Fig. 23). At $\sim 4.6 \mathrm{Ma}$, there is a marked increase in dust flux that continues, with variability, into the Pliocene and Pleistocene. Tiedemann et al. (1989) interpret this increase in dust flux as aridification of the Sahara. These investigators also note times of increased aridification, based on higher dust flux, at $4.3 \mathrm{Ma}, 4.0 \mathrm{Ma}$, 3.6 Ma, 2.1 Ma, and 0.8 Ma. The data from paleosols in our study and that of Menéndez et al. (2019) indicate several periods of African dust delivery to the Canary Islands between $\sim 4.8$ and $2.8 \mathrm{Ma}, \sim 3.0-2.9 \mathrm{Ma}$, $\sim 2.3-1.46 \mathrm{Ma}$, and at $\sim 0.4 \mathrm{Ma}$. Thus, the Canary Islands record at least 9 periods of paleosol formation, characterized by dust inputs from Africa, between $\sim 4.8 \mathrm{Ma}$ and $\sim 0.4 \mathrm{Ma}$, consistent with the ODP Site 659 record. The overall conclusion from this is that an arid Sahara has been in existence, at least intermittently, for much of the past $\sim 5 \mathrm{Myr}$.

The Sahara is not the only source of dust from Africa, however. Modern satellite imagery (see examples in Muhs et al., 2010) shows that dust from south of the Sahara is transported west from Africa during periodic droughts of the Sahel region (Fig. 1). Studies of modern dust collected off the coast of Africa in latitudinal transects show consistently that particles originating from the Sahara have, within the clay fraction, abundant mica and much less kaolinite (Chester et al., 1972; Caquineau et al., 1998; Stuut et al., 2005). In contrast, farther south, offshore from the Sahel region, dust has less mica and much more kaolinite. Muhs et al. (2010) pointed out that this trend is related to soil 
(a)
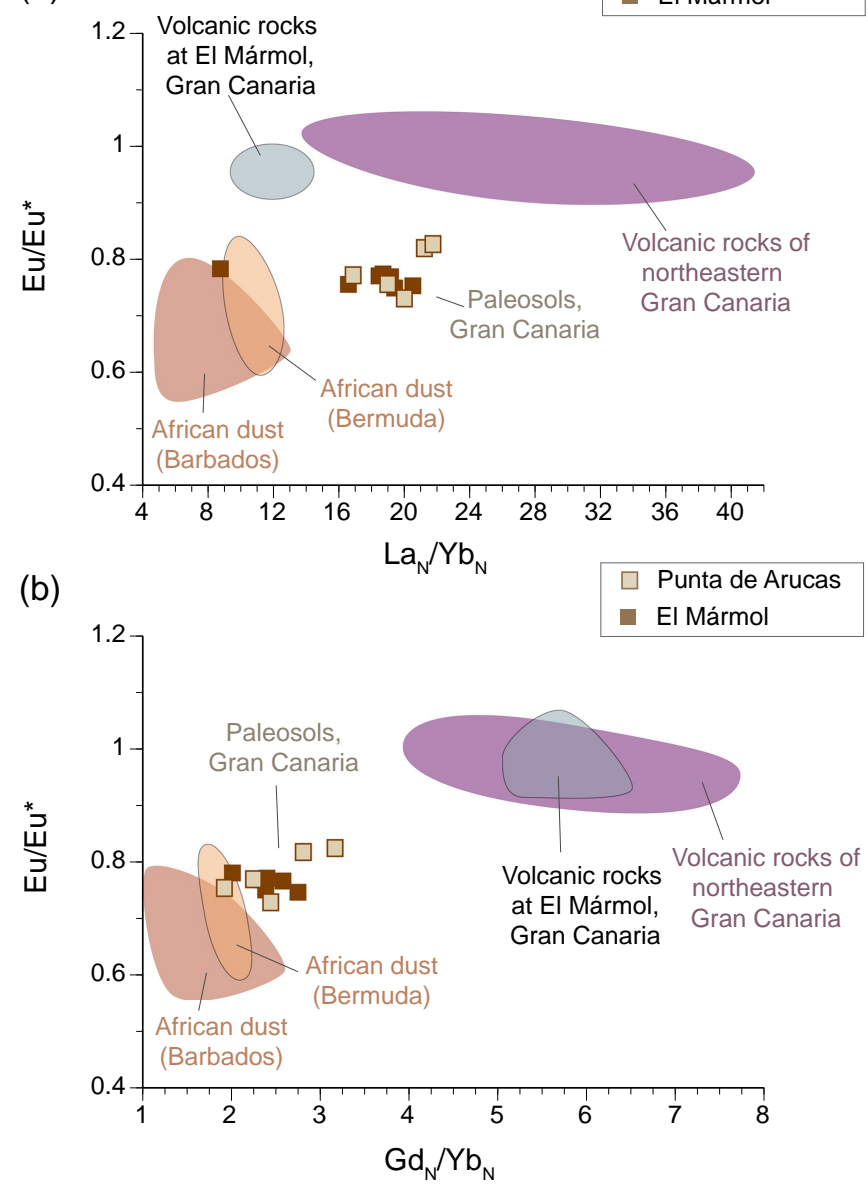

Fig. 22. Plots of: (a) $\mathrm{La}_{\mathrm{N}} / \mathrm{Yb}_{\mathrm{N}}$ vs. $\mathrm{Eu} / \mathrm{Eu}^{*}$ and (b) $\mathrm{Gd}_{\mathrm{N}} / \mathrm{Yb}_{\mathrm{N}}$ vs. $\mathrm{Eu} / \mathrm{Eu}^{*}$ in paleosols at El Mármol and Punta de Arucas, Gran Canaria compared to overlying and underlying basalts (data from this study), other volcanic rocks of northeastern Gran Canaria (data from Aulinas et al., 2010), and African dust collected on Barbados (data from Muhs et al. [2007, 2010]) and Bermuda (Muhs et al. [2012]).

geography, with minimally weathered Entisols and Aridisols in the Sahara supplying greater detrital mica, and much more weathered tropical Inceptisols, Alfisols, Ultisols, and Oxisols supplying greater pedogenically derived kaolinite.

In the paleosols studied here, all contain smectite, mica, and kaolinite (Figs. 11, 14, 15). Based on XRD peak heights or peak areas, some of the paleosols we studied likely contain as much or more kaolinite as mica. Although it could be argued that kaolinite can be produced in soils, including those of the Canary Islands, by weathering of primary minerals or other clay minerals, the link of kaolinite formation in soils to relatively warm, humid climates is well established (see review in Birkeland, 1999). Furthermore, at least in the case of the paleosols at Agua Tres Piedras on Fuerteventura, the soils have built up in highly calcareous marine or aeolian sands. This has the effect of maintaining a high soil $\mathrm{pH}$ and buffering the soil system from intense chemical weathering. The survival of marine-skeletal-derived calcite particles in the paleosols themselves argues for minimal leaching over the periods of pedogenesis (Fig. 10). It can be inferred from this, therefore, that much or all of the kaolinite in these paleosols is detrital, part of the suite of minerals delivered to the Canary Islands from African dust. The relatively high abundance of kaolinite, relative to mica, in many of these paleosols indicates that during the periods of soil formation in the Pliocene and early Pleistocene, at least some of the dust was likely derived from the Sahel.
We can again compare the implications of these observations with what is observed in offshore records, this time from ODP Site 660, a core raised from southeast of the Cape Verde Islands (Fig. 1). We note that this core is located in an area that at present receives dust mainly from the Sahel region. The long-term record of dust flux to ODP Site 660 has also been estimated by Tiedemann et al. (1989) over the $\sim 6.5 \mathrm{Myr}$ period of record in the core (Fig. 23). Dust flux is relatively low from $\sim 6.5 \mathrm{Ma}$ to $\sim 3.9-3.8 \mathrm{Ma}$ and increases markedly after that. This is interpreted to be the start of (periodic) aridification of the Sahel region and may explain the presence of kaolinite in the paleosols studied here.

\section{Conclusions}

The age of the Sahara Desert, the world's largest warm-climate desert, has been controversial, with a wide range of ages having been proposed. Possible geologic records of the Sahara's age found within the desert itself are rare and what few records exist have little or no age control. Evidence of a dry Sahara Desert can be found in areas offshore, however, where fine-grained (silts and clays) aeolian sediments have been transported. Archives of such deposition have been studied mostly in deep-sea cores raised from the eastern Atlantic Ocean.

An alternative method of investigating the age of the Sahara comes from buried paleosols that retain long-range-transported dust. This dust serves as an important soil parent material on islands downwind from the desert, such as the Canary Islands, and previous studies have confirmed delivery of dust to these islands in the Holocene and Pleistocene. On Fuerteventura, six paleosols are found intercalated with Pliocene marine sands and aeolianite, with the entire package likely dating to between $\sim 4.8 \mathrm{Ma}$ and $\sim 2.8 \mathrm{Ma}$. On Gran Canaria, paleosols are found between basalt flows dating to $\sim 3.0-2.9 \mathrm{Ma}$ and $\sim 0.4 \mathrm{Ma}$.

Paleosols from both islands contain quartz and mica, minerals that are rare in rocks of these basalt-dominated islands. Analyses of major element geochemistry shows enrichments of $\mathrm{K}_{2} \mathrm{O}$ and $\mathrm{SiO}_{2}$ in the paleosols that coincide with the horizons where mica and quartz are found. Trace element geochemistry, using immobile element abundances, expressed as plots of Sc-Th-La, Sc-Th-Ta x 10, Sc-Hf-Th, Cr/10Hf-Th, $\mathrm{La}_{\mathrm{N}} / \mathrm{Yb}_{\mathrm{N}}$ vs. Eu/Eu*, and $\mathrm{Gd}_{\mathrm{N}} / \mathrm{Yb}_{\mathrm{N}}$ vs. Eu/Eu* can be compared to abundances of these elements in modern African dust and local island bedrock. Results indicate that paleosols on both islands have compositions with intermediate values between these two possible parent materials, requiring at least some input of African dust. Based on results presented here and a recently published study by other investigators, 9 paleosols record delivery of African dust to the Canary Islands between $\sim 4.8-2.8 \mathrm{Ma}, \sim 3.0-2.9 \mathrm{Ma}, \sim 2.3-1.46 \mathrm{Ma}$, and $\sim 0.4 \mathrm{Ma}$. Our results agree with deep-sea records off the coast of west Africa that have proposed increased dust fluxes to the eastern Atlantic Ocean at about the same time as the oldest of the paleosols we studied. We conclude, therefore, that the Sahara Desert has been in existence as an arid-region dust source, at least intermittently, for much of the Pliocene and all of the Pleistocene.

\section{Acknowledgments}

The work by U.S. Geological Survey (USGS) authors is supported by the Climate Research and Development Program of the USGS. Field work in this study for Muhs was supported by the Farouk El-Baz Award of the Geological Society of America, and we thank Dr. El-Baz for his support and encouragement of this project. Kaj Hoernle (University of Kiel, Kiel, Germany) kindly provided unpublished geochemical data from Basal Complex rocks he studied on Fuerteventura (Hoernle and Tilton, 1991). We thank Jeff Pigati and Natalie Latysh (both USGS), two anonymous reviewers, and editor Thomas Algeo for helpful comments on an earlier version of this paper. Any use of trade, firm, or product names is for descriptive purposes only and does not imply endorsement by the U.S. Government. Major and trace element data generated in this 


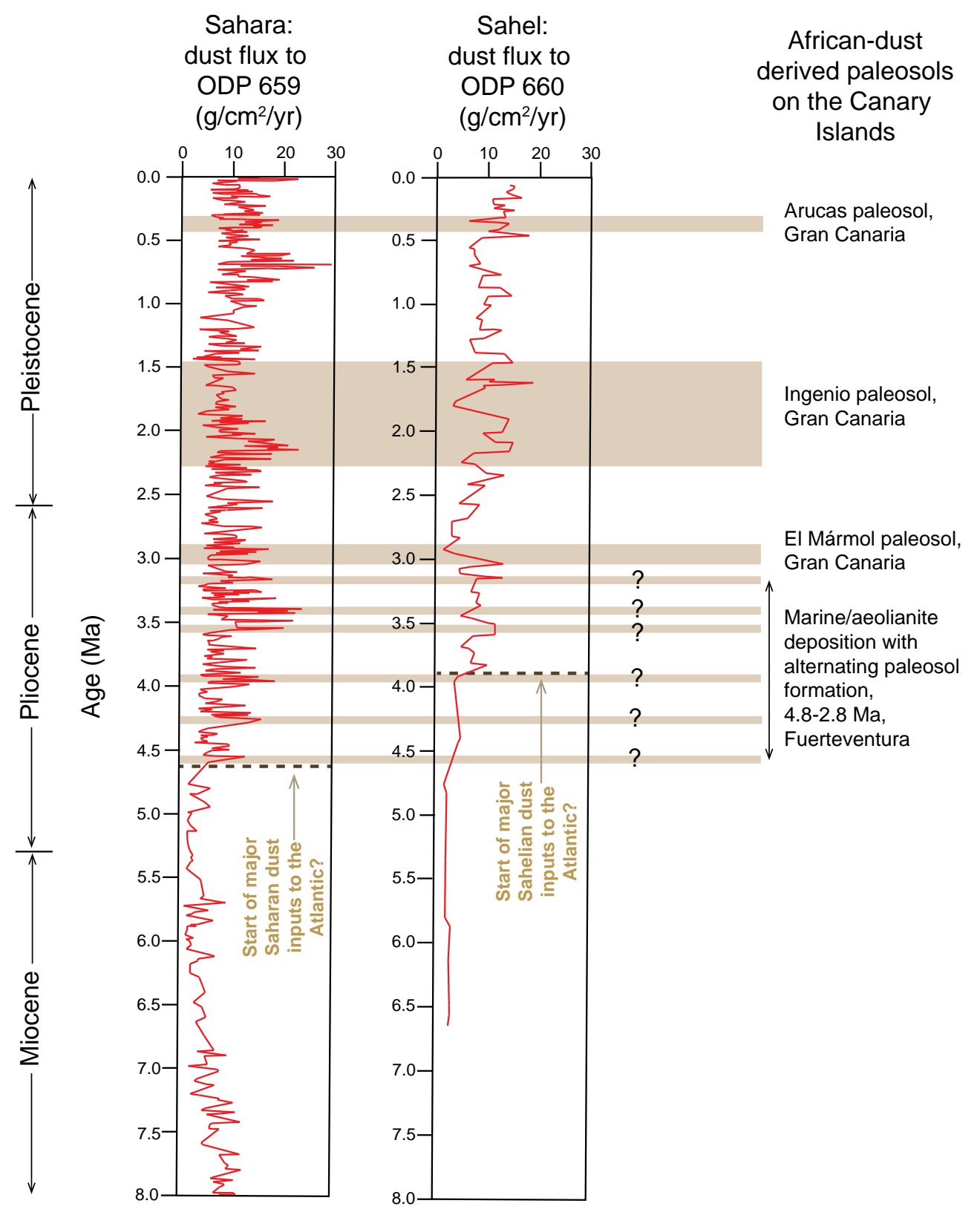

Fig. 23. Plots of mass accumulation rates of siliciclastic sediment, considered to be aeolian, in Ocean Drilling Program (ODP) cores 659 and 660, taken off western Africa, downwind of major dust pathways (see Fig. 1 for localities; data from Tiedemann et al., 1989). Also shown for comparison are times of inferred African dust deposition in paleosols on the Canary Islands, based on data in Menéndez et al. (2018) for Ingenio (see Fig. 1 for locality) and this study (all other localities). Note that the placement of times of paleosol formation on Fuerteventura is hypothetical (except for bracketing ages), as shown by queries. Dashed lines show times of transition from lower dust flux to substantially higher dust flux from the Sahara (to ODP 659) and the Sahel (to ODP 660) in the Pliocene.

El Mármol paleosol,

\section{Gran Canaria}

Marine/aeolianite deposition with alternating paleosol formation,

4.8-2.8 Ma, Fuerteventura

study are available at: https://doi.org/10.5066/P90FF7KF.

\section{Appendix A. Supplementary data}

Supplementary data to this article can be found online at https:// doi.org/10.1016/j.palaeo.2019.109245.

\section{References}

Ahijado, A., Casillas, R., Hernández-Pacheco, A., 2001. The dyke swarms of the Amanay Massif, Fuerteventura, Canary Islands (Spain). J. Asian Earth Sci. 19, 333-345.

Allibon, J., Bussy, F., Lewin, É., Darbellay, B., 2011. The tectonically controlled emplacement of a vertically sheeted gabbro-pyroxenite intrusion: feeder-zone of an oceanisland volcano (Fuerteventura, Canary Islands). Tectonophysics 500, 78-97.

Ancochea, E., Brändle, J.L., Cubas, C.R., Hernán, F., Huertas, M.J., 1993. La Serie I de la Isla de Fuerteventura. Real Academia de Ciencas, Exactas, Físicas y Naturales de Madrid, Serie de Ciencas Naturales 27 (151 pp).

Ancochea, E., Brändle, J.L., Cubas, C.R., Hernán, F., Huertas, M.J., 1996. Volcanic complexes in the eastern ridge of the Canary Islands: the Miocene activity of the island of Fuerteventura. J. Volcanol. Geotherm. Res. 70, 183-204.

Aulinas, M., Gimeno, D., Fernandez-Turiel, J.L., Font, L., Perez-Torrado, F.J., RodriguezGonzalez, A., Nowell, G.M., 2010. Small-scale mantle heterogeneity on the source of the Gran Canaria (Canary Islands) Pliocene-Quaternary magmas. Lithos 119, 377-392.

Balcells, R., Barrera, J.L., Gómez, J.A., 1991. Geological Map. Isla de Fuerteventura, scale $1,100,000$.

Balcells, R., Barrera, J.L., Gómez, J.A., 1992. Geological Map 21-21/21-22. Isla de Gran Canaria, scale 1, 100,000.

Betancort, J.F., Lomoschitz, A., Meco, J., 2016. Early Pliocene fishes (Chondrichthyes, Osteichthyes) from Gran Canaria and Fuerteventura (Canary Islands, Spain). Estud. Geol. 72, 1-15.

Bhatia, M.R., Crook, K.A.W., 1986. Trace element characteristics of graywackes and tectonic setting discrimination of sedimentary basins. Contrib. Mineral. Petrol. 92, 181-193.

Birkeland, P.W., 1999. Soils and Geomorphology. Oxford University Press, New York (430 pp).

Budahn, J.R., Schmitt, R.A., 1985. Petrogenetic modeling of Hawaiian tholeiitic basalts: a geochemical approach. Geochim. Cosmochim. Acta 49, 67-87.

Budahn, J.R., Wandless, G.A., 2002. Instrumental neutron activation by long count. U.S. Geological Survey Open-File Report OF-02-0223, Y1-Y9.

Caquineau, S., Gaudichet, A., Gomes, L., Magonthier, M.-C., Chatenet, B., 1998. Saharan dust: clay ratio as a relevant tracer to assess the origin of soil-derived aerosols. Geophys. Res. Lett. 25, 983-986.

Carracedo, J.C., Troll, V.R., 2016. The Geology of the Canary Islands. Elsevier, Amsterdam (621 p).

Carracedo, J.C., Pérez Torrado, F.J., Ancochea, E., Meco, J., Hernán, F., Cubas, C.R., Casillas, R., Rodríguez Badiola, E., Ahijado, A., 2002. Cenozoic volcanism II: the 
Canary Islands. In: Gibbons,W., Moreno, T. (Eds.), The Geology of Spain. The Geological Society, London, 439-472.

Carracedo, J.C., Torrado, F.J.P., Meco, J., 2005. La gea: Análisis de una isla en estado post-erosivo de desarrollo. In: Delgado, O.R. (Ed.), Patrimonio Natural de la isla de Fuerteventura. Gran Canaria, Centro de la Cultura Popular Canaria, pp. 27-44.

Chester, R., Elderfield, H., Griffin, J.J., Johnson, L.R., Padgham, R.C., 1972. Eolian dust along the eastern margins of the Atlantic Ocean. Mar. Geol. 13, 91-105.

Claussen, M., Kubatzki, C., Brovkin, V., Ganopolski, A., Hoelzmann, P., Pachur, H.-J., 1999. Simulation of an abrupt change in Saharan vegetation in the mid-Holocene. Geophys. Res. Lett. 26, 2037-2040.

Coello, J., Cantagrel, J.-M., Hernán, F., Fúster, J.-M., Ibarrola, E., Ancochea, E., Casquet, C., Jamond, C., Díaz de Téran, J.-R., Cendrero, A., 1992. Evolution of the eastern volcanic ridge of the Canary Islands based on new K-Ar data. J. Volcanol. Geotherm. Res. 53, 251-274.

Delany, A.C., Delany, A.C., Parkin, D.W., Griffin, J.J., Goldberg, E.D., Reimann, B.E.F., 1967. Airborne dust collected at Barbados. Geochim. Cosmochim. Acta 31, 885-909.

deMenocal, P.B., 1995. Plio-Pleistocene African climate. Science 270, 53-59.

deMenocal, P.B., Ortiz, J., Guilderson, T., Sarnthein, M., 2000. Coherent high- and lowlatitude climate variability during the Holocene warm period. Science 288, 2198-2202.

Demény, A., Vennemann, T.W., Hegner, E., Ahijado, A., Casillas, R., Nagy, G., Homonnay, Z., Gutierrez, M., Szabo, Cs, 2004. H, O, Sr, Nd, and Pb isotopic evidence for recycled oceanic crust in the Transitional Volcanic Group of Fuerteventura, Canary Islands, Spain. Chem. Geol. 205, 37-54.

Dupont, L.M., Beug, H.-J., Stalling, H., Tiedemann, R., 1989. First palynological results from Site 658 at $21^{\circ} \mathrm{N}$ off northwest Africa: Pollen as climate indicators. Proceedings of the Ocean Drilling Program, Scientific Results 108, 93-111.

Fanning, D.S., Keramidas, V.Z., 1977. Micas. In: Dixon, J.B., Weed, S.B. (Eds.), Minerals in Soil Environments. Madison, Soil Science Society of America, pp. 195-258.

Fuster, J.M., Cendrero, A., Gastesi, P., Ibarrola, E., Lopez Ruiz, J., 1968a. Geology and Volcanology of the Canary Islands: Fuerteventura. Instituto Lucas Mallada, Consejo Superior de Investigaciones Cientificas, Madrid (239 pp).

Fuster, J.M., Hernandez-Pacheco, A., Muñoz, M., Rodriguez Badiola, E., Garcia Cacho, L., 1968b. Geology and Volcanology of the Canary Islands: Gran Canaria. Instituto Lucas Mallada, Consejo Superior de Investigaciones Cientificas, Madrid (243 pp).

Geldmacher, J., Hoernle, K., Bogaared, P.v.d., Duggen, S., Werner, R., 2005. New ${ }^{40} \mathrm{Ar} /{ }^{39} \mathrm{Ar}$ age and geochemical data from seamounts in the Canary and Madeira volcanic provinces: support for the mantle plume hypothesis. Earth Planet. Sci. Lett. 237, 85-101.

Glaccum, R.A., Prospero, J.M., 1980. Saharan aerosols over the tropical North Atlantic mineralogy. Mar. Geol. 37, 295-321.

Greenough, J.D., Dostal, J., Mallory-Greenough, L.M., 2005. Igneous rock associations 4. Oceanic island volcanism 1. Mineralogy and petrology. Geosci. Can. 32, 29-45.

Guieu, C., Loÿe-Pilot, M.-D., Ridame, C., Thomas, C., 2002. Chemical characterization of the Saharan dust end-member: some biogeochemical implications for the western Mediterranean Sea. J. Geophys. Res. 107 (D15), 4258. https://doi.org/10.1029/ 2001JD000582.

Guillou, H., Carracedo, J.C., Paris, R., Torrado, F.J.P., 2004a. Implications for the early shield-stage evolution of Tenerife from K/Ar ages and magnetic stratigraphy. Earth Planet. Sci. Lett. 222, 599-614.

Guillou, H., Torrado, F.J.P., Machin, A.R.H., Carracedo, J.C., Gimeno, D., 2004b. The Plio-Quaternary volcanic evolution of Gran Canaria based on new K-Ar ages and magnetostratigraphy. J. Volcanol. Geotherm. Res. 135, 221-246.

Hobson, A., Bussy, F., Hernandez, J., 1998. Shallow-level migmatization of gabbros in a metamorphic contact aureole, Fuerteventura Basal complex, Canary Islands. J. Petrol. 39, 1025-1037.

Hoernle, K., Schmincke, H.-U., 1993. The petrology of the tholeiites through melilite nephelinites on Gran Canaria, Canary Islands: crystal fractionation, accumulation, and depths of melting. J. Petrol. 34, 573-597.

Hoernle, K.A., Tilton, G.R., 1991. Sr-Nd-Pb isotope data for Fuerteventura (Canary Islands) basal complex and subaerial volcanics: applications to magma genesis and evolution. Schweiz. Mineral. Petrogr. Mitt. 71, 3-18.

Holloway, M.I., Bussy, F., 2008. Trace element distribution among rock-forming minerals from metamorphosed to partially molten basic igneous rocks in a contact aureole (Fuerteventura, Canaries). Lithos 102, 616-639.

Hooghiemstra, H., Lézine, A.-M., Leroy, S.A.G., Dupont, L., Marret, F., 2006. Late Quaternary palynology in marine sediments: a synthesis of the understanding of pollen distribution patterns in the NW African setting. Quat. Int. 148, 29-44.

Huerta, P., Rodríguez-Berriguete, Á., Martín-García, R., Martín-Pérez, A., Fernández, Á.L.I., Alonso-Zarza, A.M., 2015. The role of climate and aeolian dust input in calcrete formation in volcanic islands (Lanzarote and Fuerteventura, Spain). Palaeogeogr. Palaeoclimatol. Palaeoecol. 417, 66-79.

Jutzeler, M., Schmincke, H.-U., Sumita, M., 2010. The incrementally zoned Miocene Ayagaures ignimbrite (Gran Canaria, Canary Islands). J. Volcanol. Geotherm. Res. 196, 1-19.

Kroepelin, S., 2006. Revisiting the age of the Sahara Desert. Science 312, 1138.

Land, L.S., 1973. Holocene meteoric dolomitization of Pleistocene limestones, North Jamaica. Sedimentology 20, 411-424.

Mahowald, N.M., Muhs, D.R., Levis, S., Rasch, P.J., Yoshioka, M., Zender, C.S., Luo, C., 2006. Change in atmospheric mineral aerosols in response to climate: last glacial period, preindustrial, modern, and doubled carbon dioxide climates. J. Geophys. Res. 111, D10202. https://doi.org/10.1029/2005JD006653.

Mason, B., Moore, C.B., 1982. Principles of Geochemistry. Wiley, New York, 344 pp.

McLennan, S.M., 1989. Rare earth elements in sedimentary rocks: influence of provenance and sedimentary processes. Rev. Mineral. 21, 169-200.

McTainsh, G.H., Walker, P.H., 1982. Nature and distribution of Harmattan dust. Z.
Geomorphol. 26, 417-435.

Meco, J., Stearns, C.E., 1981. Emergent littoral deposits in the eastern Canary Islands. Quat. Res. 15, 199-208.

Meco, J., Guillou, H., Carracedo, J.C., Lomoschitz, A., Ramos, A.J.G., Rodríguez Yánez, J.J., 2002. The maximum warmings of the Pleistocene world climate recorded in the Canary Islands. Palaeogeogr. Palaeoclimatol. Palaeoecol. 185, 197-210.

Meco, J., Ballester, J., Betancort, J.F., Scaillet, S., Guillou, H., Lomoschitz, A., Carracedo, J.C., Petit-Maire, N., Cilleros, A., Medina, P., Soler-Onís, E., Meco, J.M., 2005. Paleoclimatología del Neógeno en las Islas Canarias: Mioceno y Plioceno. Ministerio de Medio Ambiente, Universidad de Las Palmas de Gran Canaria, Las Palmas, 149 pp.

Meco, J., Ballester, J., Betancort, J.F., Cilleros, A., Scaillet, S., Guillou, H., Carracedo, J.C., Lomoschitz, A., Petit-Maire, N., Ramos, A.J.G., Perera, N., Meco, J.M., 2006. Paleoclimatología del Neógeno en las Islas Canarias: Geliense, Pleistoceno y Holoceno. Ministerio de Medio Ambiente, Universidad de Las Palmas de Gran Canaria, Las Palmas, 203 pp.

Meco, J., Scaillet, S., Guillou, H., Lomoschitz, A., Carracedo, J.C., Ballester, J., Betancort, J.-F., Cilleros, A., 2007. Evidence for long-term uplift on the Canary Islands from emergent Mio-Pliocene littoral deposits. Glob. Planet. Chang. 57, 222-234.

Meco, J., Muhs, D.R., Fontugne, M., Ramos, A.J.G., Lomoschitz, A., Patterson, D., 2011. Late Pliocene and Quaternary Eurasian locust infestations in the Canary Archipelago. Lethaia 44, 440-454.

Meco, J., Koppers, A.A.P., Miggins, D.P., Lomoschitz, A., Betancort, J.-F., 2015. The Canary record of the evolution of the North Atlantic Pliocene: New ${ }^{40} \mathrm{Ar} /{ }^{39} \mathrm{Ar}$ ages and some notable palaeontological evidence. Palaeogeogr. Palaeoclimatol. Palaeoecol. 435, 53-69.

Meco, J., Lomoschitz, A., Betancort, J.-F., 2016. Early Pliocene tracer of North Atlantic and South Pacific Sea surface currents: Janthina typica (Bronn, 1860) (Mollusca: Gastropoda). Revista Mexicana de Ciencias Geológicas 33, 192-197.

Menéndez, I., Mangas, J., Tauler, E., Barrón, V., Torrent, J., Betancort, J.F., Santana, Á. Recio, J.M., Quevedo-González, L.A., Alonso, I., Méndez-Ramos, J., 2019. Aeolian influx and related environmental conditions on Gran Canaria during the early Pleistocene. Quat. Res. 91, 35-50.

Micheels, A., Eronen, J., Mosbrugger, V., 2009. The Miocene climate response to a modern Sahara desert. Glob. Planet. Chang. 67, 193-204.

Moore, D.M., Reynolds, R.C., Jr., 1997. X-Ray Diffraction and the Identification and Analysis of Clay Minerals. Oxford University Press, Oxford, 378 pp.

Muhs, D.R., 2013. The geologic records of dust in the Quaternary. Aeolian Res. 9, 3-48.

Muhs, D.R., Budahn, J.R., Prospero, J.M., Carey, S.N., 2007. Geochemical evidence for African dust inputs to soils of western Atlantic islands: Barbados, the Bahamas, and Florida. J. Geophys. Res. 112, F02009. https://doi.org/10.1029/2005JF000445.

Muhs, D.R., Budahn, J., Skipp, G., Prospero, J.M., Patterson, D., Bettis III, E.A., 2010 Mineralogical and geochemical evidence for Sahara and Sahel dust additions to Quaternary soils on Lanzarote, eastern Canary Islands, Spain. Terra Nova 22, 399-410.

Muhs, D.R., Budahn, J.R., Prospero, J.M., Skipp, G., Herwitz, S.R., 2012. Soil genesis on the island of Bermuda in the Quaternary: the importance of African dust transport and deposition. J. Geophys. Res. 117, F03025. https://doi.org/10.1029/ 2012JF002366.

Muhs, D.R., Meco, J., Simmons, K.R., 2014. Uranium-series ages of corals, sea level history, and palaeozoogeography, Canary Islands, Spain: an exploratory study for two Quaternary interglacial periods. Palaeogeogr. Palaeoclimatol. Palaeoecol. 394, 99-118.

Muhs, D.R., Budahn, J.R., Skipp, G., McGeehin, J.P., Meco, J., 2016. A long-term Quaternary record of dual-source African dust inputs to soils on the Canary Islands, Spain. Geol. Soc. Am. Abstr. Programs 48 (7). https://doi.org/10.1130/abs/2016AM284051.

Muhs, D.R., Pigati, J.S., Schumann, R.R., Skipp, G.L., Porat, N., DeVogel, S.B., 2018. Quaternary sea-level history and the origin of the northernmost coastal aeolianites in the Americas: Channel Islands National Park, California, USA. Palaeogeogr. Palaeoclimatol. Palaeoecol. 491, 38-76.

Mulitza, S., Prange, M., Stuut, J.-B., Zabel, M., von Dobeneck, T., Itambi, A.C., Nizou, J., Schulz, M., Wefer, G., 2008. Sahel megadroughts triggered by glacial slowdowns of Atlantic meridional overturning. Paleoceanography 23, PA4206. https://doi.org/10. 1029/2008PA001637.

Mulitza, S., Heslop, D., Pittauerova, D., Fischer, H.W., Meyer, I., Stuut, J.-B., Zabel, M., Mollenhauer, G., Collins, J.A., Kuhnert, H., Schulz, M., 2010. Increase in African dust flux at the onset of commercial agriculture in the Sahel region. Nature 466, 226-228.

Pflaumann, U., Sarnthein, M., Ficken, K., Grothmann, A., Winkler, A., 1998. Variations in eolian and carbonate sedimentation, sea-surface temperature, and productivity over the last 3 M.Y. at Site 958 off northwest Africa. Proceedings of the Ocean Drilling Program, Scientific Results 159T, 3-16.

Pokras, E.M., Ruddiman, W.F., 1989. Evolution of south Saharan/Sahelian aridity based on freshwater diatoms (genus Melosira) and opal phytoliths: Sites 662 and 664. Proceedings of the Ocean Drilling Program, Scientific Results 108, 143-148.

Prospero, J.M., Bonatti, E., Schubert, C., Carlson, T.N., 1970. Dust in the Caribbean atmosphere traced to an African dust storm. Earth Planet. Sci. Lett. 9, 287-293.

Prospero, J.M., Ginoux, P., Torres, O., Nicholson, S.E., Gill, T.E., 2002. Environmental characterization of global sources of atmospheric soil dust identified with the Nimbus 7 Total ozone Mapping Spectrometer (TOMS) absorbing aerosol product. Rev. Geophys. 40 (1), 1-31.

Quade, J., Dente, E., Armon, M., Ben Dor, Y., Morin, E., Adam, O., Enzel, Y., 2018. Megalakes in the Sahara? A review. Quat. Res. 90, 253-275.

Roettig, C.-B., Varga, G., Sauer, D., Kolb, T., Wolf, D., Makowski, V., Espejo, J.M.R., Zöller, L., Faust, D., 2019. Characteristics, nature, and formation of palaeosurfaces within dunes on Fuerteventura. Quat. Res. 91, 4-23.

Ruddiman, W.F., Sarnthein, M., Backman, J., Baldauf, J.G., Curry, W., Dupont, L.M., 
Janecek, T., Pokras, E.M., Raymo, E.M., Stabell, B., Stein, R., Tiedemann, R., 1989. Late Miocene to Pleistocene evolution of climate in Africa and the low-latitude Atlantic: overview of Leg 108 results. Proceedings of the Ocean Drilling Program, Scientific Results 108, 463-484.

Sarnthein, M., Tetzlaff, G., Koopmann, B., Wolter, K., Pflaumann, U., 1981. Glacial and interglacial wind regimes over the eastern subtropical Atlantic and north-west Africa. Nature 293, 193-196.

Sarnthein, M., Thiede, J., Pflaumann, U., Erlenkeuser, H., Fütterer, D., Koopmann, B., Lange, H., Seibold, E., 1982. Atmospheric and oceanic circulation patterns off northwest Africa during the past 25 million years. In: Von Rad, U., Hinz, K., Sarnthein, M., Seibold, E. (Eds.), Geology of the Northwest African Continental Margin. Springer-Verlag, Berlin, pp. 545-604.

Schmincke, H.-U., 1976. Geology of the Canary Islands. In: Kunkel, G. (Ed.), Biogeography and Ecology in the Canary Islands. W. Junk, The Hague, pp. 67-184.

Schuster, M., Duringer, P., Ghienne, J.-F., Vignaud, P., Mackaye, H.T., Likius, A., Brunet, M., 2006. The age of the Sahara Desert. Science 311, 821.

Sincell, M., 1999. A wobbly start for the Sahara. Science 285, 325.

Skonieczny, C., McGee, D., Winckler, G., Bory, A., Bradtmiller, L.I., Kinsley, C.W., Polissar, P.J., De Pol-Holz, R., Rossignol, L., Malaizé, B., 2019. Monsoon-driven Saharan dust variability over the past 240,000 years. Science Advances 5: easv1887, 1-8.

Stein, R., Sarnthein, M., 1984. Late Neogene events of atmospheric and oceanic circulation offshore northwest Africa: high-resolution record from deep-sea sediments. Palaeoecol. Afr. 16, 9-36.

Stuut, J.-B., Zabel, M., Raymeyer, V., Helmke, P., Schefuß, E., Lavik, G., Schneider, R., 2005. Provenance of present-day eolian dust collected off NW Africa. J. Geophys. Res. 110, D04202. https://doi.org/10.1029/2004JD005161.

Swezey, C., 1999. A very old Sahara. Science 286, 239.

Swezey, C.S., 2006. Revisiting the age of the Sahara Desert. Science 312, 1138-1139.
Swezey, C.S., 2009. Cenozoic stratigraphy of the Sahara, Northern Africa. J. Afr. Earth Sci. 53, 89-121.

Taylor, S.R., McLennan, S.M., 1985. The Continental Crust: Its Composition and Evolution. Oxford, Blackwell Scientific Publications, 312 pp.

Thiede, J., Suess, E., Müller, P.J., 1982. Late Quaternary fluxes of major sediment components to the sea floor at the northwest African continental slope. In: Von Rad, U. Hinz, K., Sarnthein, M., Seibold, E. (Eds.), Geology of the Northwest African Continental Margin. Springer-Verlag, Berlin, pp. 605-631.

Tiedemann, R., Sarnthein, M., Stein, R., 1989. Climatic changes in the western Sahara: Aeolo-marine sediment record of the last 8 million years. Proceedings of the Ocean Drilling Program, Scientific Results 108, 241-277.

Tjallingii, R., Claussen, M., Stuut, J.-B.W., Fohlmeister, J., Jahn, A., Bickert, T., Lamy, F., Röhl, U., 2008. Coherent high- and low-latitude control of the northwest African hydrological balance. Nat. Geosci. 1, 670-675.

Tornare, E., Pilet, S., Bussy, F., 2016. Magma differentiation in vertical conduits revealed by the complementary study of plutonic and volcanic rocks from Fuerteventura (Canary Islands). J. Petrol. 57, 2221-2250.

Van der Does, M., Korte, L.F., Munday, C.I., Brummer, G.-J.A., Stuut, J.-B.W., 2016. Particle size traces modern Saharan dust transport and deposition across the equatorial North Atlantic. Atmos. Chem. Phys. 16, 13697-13710.

Van der Does, M., Pourmand, A., Sharifi, A., Stuut, J.-B.W., 2018. North African mineral dust across the tropical Atlantic Ocean: Insights from dust particle size, radiogenic SrNd-Hf isotopes and rare earth elements (REE). Aeolian Res. 33, 106-116.

Wilke, B.M., Duke, B.J., Jimoh, W.L.O., 1984. Mineralogy and chemistry of Harmattan dust in northern Nigeria. Catena 11, 91-96.

Zhang, Z., Ramstein, G., Schuster, M., Li, C., Contoux, C., Yan, Q., 2014. Aridification of the Sahara Desert caused by Tethys Sea shrinkage during the late Miocene. Nature $513,401-404$. 